Article

\title{
Submagmatic to Solid-State Deformation Microstructures Recorded in Cooling Granitoids during Exhumation of Late-Variscan Crust in North-Eastern Sicily
}

\author{
Eugenio Fazio ${ }^{\mathbb{D}}$, Patrizia Fiannacca *, Damiano Russo and Rosolino Cirrincione \\ Dipartimento di Scienze Biologiche, Geologiche e Ambientali, Università di Catania, 95129 Catania, Italy; \\ eugenio.fazio@unict.it (E.F.); damiano.rss@hotmail.it (D.R.); r.cirrincione@unict.it (R.C.) \\ * Correspondence: patrizia.fiannacca@unict.it
}

Received: 17 July 2020; Accepted: 9 August 2020; Published: 13 August 2020

check for updates

\begin{abstract}
Late-Variscan granitoid rocks of trondhjemitic and granitic composition, intruded in migmatitic paragneisses in the north-eastern Peloritani Mountains (southern Italy) at $210 \mathrm{Ma}$ and $\sim 300 \mathrm{Ma}$, respectively, exhibit a range of deformation microstructures developed under a shear regime at decreasing temperatures. Non-coaxial deformation is documented by sigmoidal feldspar porphyroclasts, mica fish, and asymmetric boudins affecting tiny andalusite crystals. Late-Variscan shearing during granitoid cooling is constrained by largely represented chessboard patterns in quartz and, especially, submagmatic fractures in plagioclase, indicating deformation at high-temperature conditions $\left(\mathrm{T}>650^{\circ} \mathrm{C}\right)$, in the presence of melt. Submagmatic deformation was extensively superseded by deformation at lower temperatures. Examples of solid state-high temperature deformation-related microstructures $\left(\mathrm{T}>450^{\circ} \mathrm{C}\right.$ ) include feldspar bulging, quartz grain boundary migration, and subgrain rotation recrystallization. Finally, low temperature subsolidus microstructures $\left(\mathrm{T}<450{ }^{\circ} \mathrm{C}\right)$ consist of quartz bulging, mica kinks, and feldspar twinning and bending. A complete sequence of deformation, operating from submagmatic to low-temperature subsolidus conditions is recorded in both the older and younger granitoids, suggesting a duration of $\sim 20 \mathrm{Ma}$ for shear zone activity during post-collisional exhumation of the Variscan middle crust in southernmost Italy.
\end{abstract}

Keywords: trondhjemites; granites; post-collisional magmatism; syn-magmatic deformation; shear zones; Peloritani Mountains (southern Italy)

\section{Introduction}

Shear zones (e.g., [1] and references therein) play a fundamental role in shaping the structure and composition of the continental crust, in a number of different ways. Among these, they can control the construction of orogenic edifices [1-5], the extraction, ascent and emplacement of granitoid magmas [1,6-15], the exhumation of deep crustal rocks [16,17], and the circulation of fluids able to further influence the rheology of the crust $[18,19]$, as well as the mineral assemblage stability [19-22].

The study of shear zones can therefore provide crucial information on the evolution of the mountain belts. Nevertheless, the role played by the shear zones in controlling the building and exhumation of the orogenic crust may be particularly complicate to assess in poly-orogenic terranes, especially considering that older tectonic structures can be reactivated during subsequent orogenic cycles (e.g., [23-25]).

Well constrained Alpine shear zones are long known in the Aspromonte Massif and Peloritani Mountains from the southern Calabria-Peloritani Orogen (CPO; e.g., [1,2,26-35]). Here, Alpine tectonics locally reworked Mesozoic sedimentary rocks, as well as portions of Variscan and older basements, 
hampering the reconstruction of the pre-Alpine tectono-metamorphic evolution. In more detail, early- to late-Alpine shear zones were associated first to subduction of basement rocks and related sedimentary covers to deep crustal levels $[1,26,27]$, and then to their exhumation along detachment surfaces, causing the present-day nappe stack structure of the Peloritani Mountains and Aspromonte Massif $[1,26,27]$. On the other hand, despite late-Variscan shear zones controlled the emplacement of the granitoids from the Serre and Sila batholiths, in central and northern Calabria [15,36-44], possible Variscan shear zone occurrence in the southernmost CPO has only been suggested by $[45,46]$. More recently, [47] highlighted the likely role of late-Variscan shearing in assisting the production of metasomatic trondhjemitic rocks by infiltration metasomatism affecting late-Variscan leucogranites, in the north-eastern Peloritani Mountains.

In this contribution, we describe and discuss a variety of shear-related microstructures developed from submagmatic to low-temperature solid-state conditions, in trondhjemites and leucogranites emplaced during two separate stages of late-Variscan magmatism, at 310 Ma and $300 \mathrm{Ma}$, respectively (e.g., [48-50]), to shed light on the deformation mechanisms operating during long-lived shear zone activity associated with post-collisional exhumation.

Although the present-day features of the basement rocks of the Peloritani Mountains are the result of a complex poly-orogenic history involving Cadomian, Variscan, and Alpine tectonic events (e.g., [51] and references therein), we use microstructures, in association with existing geochronological constraints [48-50], to provide the first unequivocal evidence for the occurrence of a late-Variscan shearing event in the Peloritani Mountains. Furthermore, the documented complete sequence of deformation, operating from submagmatic to low-temperature subsolidus conditions in both the older and younger granitoids, suggests a duration of $\sim 20 \mathrm{Ma}$ for shear zone activity during post-collisional exhumation of the Variscan middle crust in southernmost Italy. Finally, our results support the location of the Peloritani basement within a peripheral branch of the East Variscan Shear Zone (EVSZ), as previously proposed by [52-55].

\section{Geo-Petrological Background}

The Peloritani Mountains, in NE Sicily (Figure 1), make up the southern termination of the Calabria-Peloritani Orogen (CPO), a poly-orogenic basement complex comprising remnants of Variscan and Cadomian mountain belts, incorporated into the Alpine-Apenninic orogenic system ([51]; and references therein). The Peloritani Belt comprises a stack of south-verging Alpine nappes, consisting mostly of Variscan basement rocks with remnants of Meso-Cenozoic covers. The belt is subdivided into two complexes with different tectono-metamorphic histories. In the southern Peloritani, the lower complex consists of sub-greenschist facies Cambrian to Carboniferous volcano-sedimentary sequences with unmetamorphosed Mesozoic sedimentary covers [56-58]. The upper complex consists of two tectonic units: (1) the Mandanici Unit, comprising dominant greenschist to lower-amphibolite facies phyllites, with interbedded levels of metabasites and subordinate marbles and calc-schists [26,46,59]; (2) the overlying Aspromonte Unit, exposed also in the adjacent Aspromonte Massif in southern Calabria, which consists of amphibolite-facies paragneisses, augen gneisses and migmatites, with minor marbles and amphibolites, diffusively intruded by late-Variscan granitoid plutons [47,60-66]. Both granitoids and host rocks are locally affected by an Alpine overprint, at 28-22 Ma $[67,68]$ and $P-T$ (pressure-temperature) peak conditions of $\sim 0.8 \mathrm{GPa}$ at $\sim 600{ }^{\circ} \mathrm{C}$ in the southern sector of Peloritani Mountains [26,27,29] that produced pseudotachylytes and cataclastic to mylonitic rocks; furthermore, a weakly metamorphosed Mesozoic-Cenozoic sedimentary cover sandwiched between the Mandanici and Aspromonte units locally occurs ([26]; and references therein).

$\mathrm{P}-\mathrm{T}$ conditions for the Variscan metamorphism, producing the main field foliation, are in the range of $\sim 0.5 \mathrm{GPa}$ at $\sim 550-680{ }^{\circ} \mathrm{C}$ for the Aspromonte Unit in the Peloritani Mountains [69], similar to those obtained for rocks of the same unit in the Aspromonte Massif $\left(0.4-0.5 \mathrm{GPa}\right.$ at $650-675^{\circ} \mathrm{C}$; [70,71]). Relatively high $\mathrm{P}$ peak values of $0.8 \mathrm{GPa}$ at $\sim 600{ }^{\circ} \mathrm{C} \sim$ and of $\sim 0.9 \mathrm{GPa}$ at $\sim 530{ }^{\circ} \mathrm{C}$ were obtained 
by [46,72], respectively, through thermodynamic modelling of garnet phyllites and schists, from both the Aspromonte and the underlying Mandanici Unit.

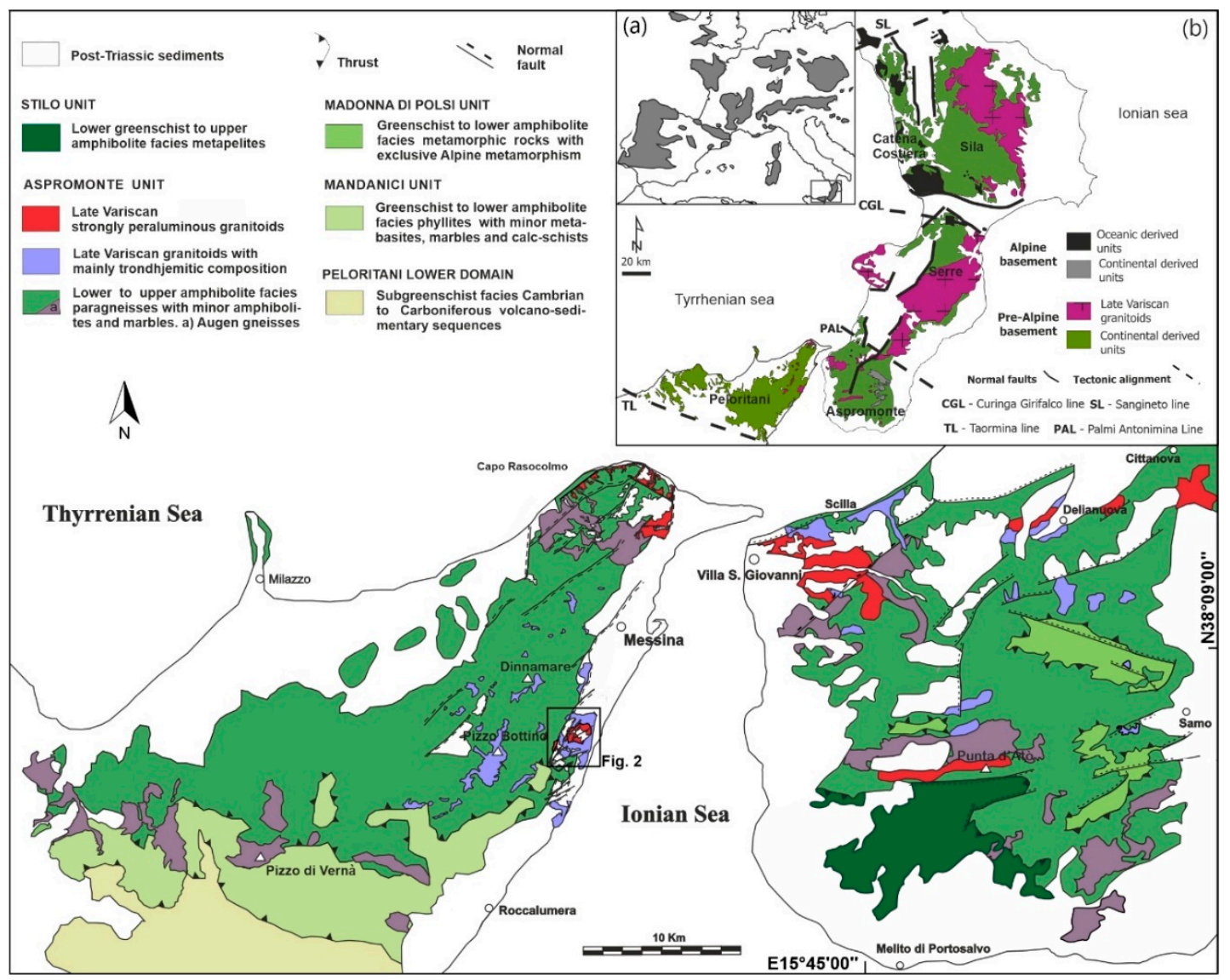

Figure 1. Geological sketch map of the northeastern Peloritani Mountains and western Aspromonte Massif with distribution of the late-Variscan granitoids (after [47]; and references therein). Insets show (a) distribution of pre-Alpine basements in western Europe and (b) distribution of Alpine and pre-Alpine basement rocks in the Calabria-Peloritani Orogen and main tectonic alignments (modified after [42]).

In particular, three blasto-deformational events have been detected in upper greenschist-facies metapelites from the north-eastern Peloritani by [46]: $\mathrm{D}_{1}$, producing an isoclinal folding schistosity $\left(\mathrm{S}_{1}\right)$, developed at $\mathrm{P} \sim 0.9 \mathrm{GPa}$ and $\mathrm{T} \sim 530{ }^{\circ} \mathrm{C}$ and only preserved as microfold hinge relics; $\mathrm{D}_{2}$, a non-coaxial deformational event, associated to metamorphic peak conditions of $\mathrm{P} \sim 0.8 \mathrm{GPa}$ and $\mathrm{T}$ $\sim 540^{\circ} \mathrm{C}$ and generating the field foliation $\left(\mathrm{S}_{2}\right)$, that consists of a pervasive crenulation schistosity; $\mathrm{D}_{3}$, a retrograde non-coaxial shearing event, developed at $0.60-0.30 \mathrm{GPa}$ and $460-420{ }^{\circ} \mathrm{C}$, and producing a schistosity surface well visible only in the porphyroclast pressure shadows, or between fragments of pinch-and-swell garnet porphyroclasts. According to [46], the reconstructed P-T path depicts a typical clockwise P-T evolution, with a prograde stage involving burial at middle-lower crustal levels during collision-related thickening, followed by a retrograde evolution during a post-collisional shearing stage, likely related to late-Variscan exhumation under an extensional regime.

A similar P-T evolution has been outlined by [72] for an amphibolite-facies garnet schist, with a baric peak at $\mathrm{P}=0.72-0.82 \mathrm{GPa}$ and $\mathrm{T}=565-585^{\circ} \mathrm{C}\left(\mathrm{D}_{1}\right)$, followed by decompression for which, however, only relatively high pressure of $\mathrm{P}=0.46-0.70 \mathrm{GPa}$ at $\mathrm{T}=500-600{ }^{\circ} \mathrm{C}$, reflecting the early stages of late-Variscan exhumation $\left(\mathrm{D}_{2}\right)$, have been constrained by the authors.

In a more general framework, the whole CPO is considered one of the peri-Gondwanan crustal blocks of the former Galatian superterrane [73] that, with neighbouring areas such as Sardinia, Corsica, West Carpathians and parts of the Alps, belonged to the future south Variscan terranes. These basement 
areas were located at the northern Paleotethys margin, while terranes such as Saxothuringia, Bohemia and Armorica faced to the north the Rheic-Rhenohercynian Ocean (e.g., [74,75]). The sequential closure of the two oceans led to the final collision and amalgamation of Gondwana, peri-Gondwanan terranes and Laurussia, finally resulting in the formation of Pangea at ca. $300 \mathrm{Ma}$. Extensive crustal anatexis and granitoid magmatism in the south Variscan terranes, at c. 320-280 Ma, is considered to have been triggered by a change from a compressional to a transtensional/transpressional regime, locally associated with significant crustal thinning and asthenosphere upwelling, producing a complex pattern of strike-slip shear zones, collectively known as East Variscan Shear Zone (EVSZ; e.g., [52,53,55,74]). According to reconstructions by $[54,55]$, the CPO was also possibly part of EVSZ.

The latest stages of the Variscan Orogeny were indeed marked also in the CPO by widespread crustal melting and voluminous granitoid magmatism [15,36,38,47,49,65,76,77]. The late-Variscan magmatism gave rise to the composite Serre and Sila batholiths in central and northern Calabria $[15,26,38,48,76-78]$, as well as to isolated anatectic plutons of weakly to strongly peraluminous trondhjemites and strongly peraluminous leucogranodiorite-leucogranites, in southern Calabria and north-eastern Sicily (Aspromonte Unit) $[36,47,49]$.

Unlike the batholiths of the Sila and Serre Massifs, which are 10-13 km thick and are emplaced into high- to low-grade metamorphic rocks, the late-Variscan granitoids of the Aspromonte Unit occur as isolated plutons of a few $\mathrm{km}^{2}$, typically emplaced into migmatitic paragneisses $[49,61,63,64,79]$.

Available geochronological constraints indicate that the late-Variscan granitoid magmatism in the southern CPO started with the emplacement of the trondhjemite plutons at $\sim 310 \mathrm{Ma}$, and was followed by the intrusion of the strongly peraluminous granitoid plutons at $\sim 300 \mathrm{Ma}$ (monazite U-Pb ID-TIMS, [48]; zircon U-Pb SHRIMP, [49,50]). The largest volumes of granitoid magmas were produced afterward more to the north, forming the Serre Batholith, in the 297.3 $\pm 3.1 \mathrm{Ma}$ to $292.2 \pm 2.6 \mathrm{Ma}$ time span (zircon U-Pb SHRIMP, [15] and references therein). Late-Variscan magmatism in the area ended with an extensive subvolcanic activity producing swarms of medium- to high-K calcalkaline dacitic-rhyodacitic to andesitic dykes [44,80-82], which intruded both the batholith and the upper crustal host rocks. These products represent the transition from a late-orogenic to a post-orogenic setting, documented by sodic-alkaline and tholeiitic Triassic basalts from northern Calabria [83] and central-western Sicily [84,85], associated with the early breakup of Pangea.

The late-Variscan strongly peraluminous leucogranodiorites and leucogranites from the Aspromonte Unit form plutons up to $\sim 40 \mathrm{~km}^{2}$ in size, typically displaying sharp discordant contacts with the upper-amphibolite facies host rocks. The rocks contain variable amounts of Al-silicates, cordierite and garnet, in addition to abundant muscovite and inherited zircon with a wide spread of ages [64], and are mostly considered as S-type granites formed by decompression melting involving muscovite \pm biotite incongruent breakdown $[49,60,61,79]$. In particular, a strong connection with a magma source similar to the paragneisses that represent the dominant rock type in the Aspromonte Unit, has been recently inferred for the Villa S. Giovanni-Capo Rasocolmo leucogranodiorites, based on diagnostic bulk rock geochemical features and zircon inherited patterns [64].

The weakly to strongly peraluminous trondhjemites crop out as small bodies displaying a variety of field relationships with the host high-grade metamorphic rocks; the largest bodies are about $10 \mathrm{~km}^{2}$ in size and their contacts range from sharp (discordant or concordant) to gradual. Trondhjemites are sometimes associated in the field with leucogranodiorites-leucogranites. The origin of the trondhjemitic rocks from the north-eastern Peloritani Mountains has been strongly debated. The rocks have been variously interpreted as the products of metasomatic alteration of metasediments [79], isochemical metamorphism of arkoses [86], partial melting of biotite paragneisses [47,60], fluid-assisted metamorphic differentiation of muscovite schists [87], and alkali metasomatism of the strongly peraluminous granites [63].

Two different types of trondhjemites occur in the Peloritani Mountains [47]: (a) magmatic trondhjemites formed at $\sim 310$ Ma by water-fluxed melting of metagreywackes at relatively high pressure 
and low temperature, close to the collision-related baric peak and (b) younger, low-Ca trondhjemitic rocks, formed by alkali metasomatism at expenses of the 300 Ma leucogranodiorites-leucogranites.

As mentioned earlier, all the granitoid rocks from the north-eastern Peloritani Mountains, were locally affected by shearing. Deformation features are rarely visible in the field, also due to the low biotite amounts ( $0-7 \%$ vol.), associated to a coarse to very coarse feldspar and quartz size. On the other hand, shear-related microstructures are commonly observed in the late-Variscan granitoids, and are particularly well developed in the Forte Cavalli area (FC area, [47]; and references therein).

Post-Variscan shear-zone activity associated with Alpine tectonics is well known in the Peloritani Mountains ([51]; and references therein), even though the development of a discernible Alpine foliation is localized at the tectonic contact between the Mandanici and Aspromonte Units [26], and in a small area northwest of Messina ([88]; and references therein). A more intense Alpine reworking of older basement rocks, producing a pervasive mylonitic foliation and an evident stretching lineation, has been widely documented by several authors in different areas of the Aspromonte Massif [1,2,28,30,33-35,70,71].

The entire Alpine deformational history in the Peloritani Mountains has been constrained by [26] by studying the mylonitic rocks developed at the contact between the Aspromonte and Mandanici units.

Such mylonites form a quite continuous horizon of $\sim 100 \mathrm{~m}$ in thickness due to repetition by near-isoclinal folding, dislocated by recent faults at the boundary between the uppermost high-grade metamorphic rocks and the underlying medium to low-grade metapelites [26]. Quartz c-axis patterns together with pseudotachylyte geothermometry constrained the shearing temperature from $\leq 600{ }^{\circ} \mathrm{C}$ to $450^{\circ} \mathrm{C}$ for the exhumation of the tectonic slices forming the Upper Complex [26,51]. Subsequently, the shear zone developed under shallower conditions, accompanied by greenschist-facies assemblages, up to very low grade to cataclastic brittle regime.

In contrast, no ultimate evidence of Variscan shearing in the Peloritani Mountains has been up to date provided. [45] proposed that late-Variscan shear-zone activity was responsible for the nappe stacking of the Peloritani orogenic edifice, based on an age of $301 \pm 2$ Ma obtained by ${ }^{39} \mathrm{Ar}-{ }^{40} \mathrm{Ar}$ dating of white mica from a mylonitic augen gneiss from the tectonic contact between the Aspromonte Unit and the underlying Mandanici Unit. Nevertheless, the age of $\sim 300 \mathrm{Ma}$ is considered to reflect the climax of high-temperature Variscan metamorphism throughout the Peloritani Mountains and the Aspromonte Massif (e.g., $[48,89,90])$, and not the nappe stacking for which an Alpine tectonic phase at 28-22 Ma has been soundly demonstrated [1,26,67].

Fiannacca et al. [46] obtained for a garnet schist of the Mandanici Unit a clockwise P-T path consistent with late-Variscan crustal thickening up to deep crustal levels $\left(\mathrm{P}=0.9 \mathrm{GPa}\right.$ at $\left.\sim 530^{\circ} \mathrm{C}\right)$ followed by exhumation along an extensional shear zone under greenschist facies conditions. Nevertheless, also in this case, no indisputable evidence about the Variscan age of the shear zone activity, was obtained.

On the other hand, clear evidence of shearing affecting late-Variscan cooling granitoids in the Forte Cavalli area of north-eastern Peloritani (Figure 2) has been recently provided by [47]. The late-Variscan granitoids in this area consist of trondhjemites and granites, which are associated in the field with upper amphibolite-facies rocks mainly comprising metasedimentary migmatites, with minor granitoid gneisses and amphibolites. Shear-related deformation, including also considerable grain size reduction, is considered by [47] to have played a significant role in aiding fluid infiltration and associated production of metasomatic trondhjemites at expense of part of the original granites; according to the above authors, the metasomatic fluids were likely released during crystallization of the large volumes of granitic magmas of the Serre Batholith.

\section{Granitoid Rocks in the Study Area}

In this section we report the main field and petrographic features of the studied rocks, largely deriving from previous work from part of the same team [47], but integrated here by new field and thin-section images, to provide the reader with an exhaustive background on these rocks, before presenting the deformation microstructures which are the focus of the present work. Studied granitoid rocks crop out in the Forte Cavalli area, in the north-eastern Peloritani Mountains (Figure 2), intruding 
upper-amphibolite facies rocks composed of dominant biotitic paragneisses and migmatites (metatexites and rare diatexites), with minor amphibolites, micaschists and granitic gneisses. The main foliation dips $35-40^{\circ}$ to NW and two main systems of brittle structures occur, with NE-SW and NNW-SSE directions.

Based on petrographic and geochemical features (see [47] for a detailed description), two main types of granitoid rocks occur in the FC area: trondhjemites s.s., with typical $\mathrm{CaO}$ contents of 1.5-3.0 wt.\%, hereafter called trondhjemites (emplacement age: $\sim 310 \mathrm{Ma} ;[19,20]$ ) and low-Ca granitoids (emplacement age: $300 \mathrm{Ma}$; [48-50]). The latter have $\mathrm{CaO}<1.50 \mathrm{wt} \%$, range in composition from granite to low-Ca trondhjemite. Both rock groups are light-colored, with a very similar appearance in the field. In fact, although grain size is typically coarse to very-coarse for the trondhjemites and medium to coarse in the low-Ca granitoids, many exceptions occur.

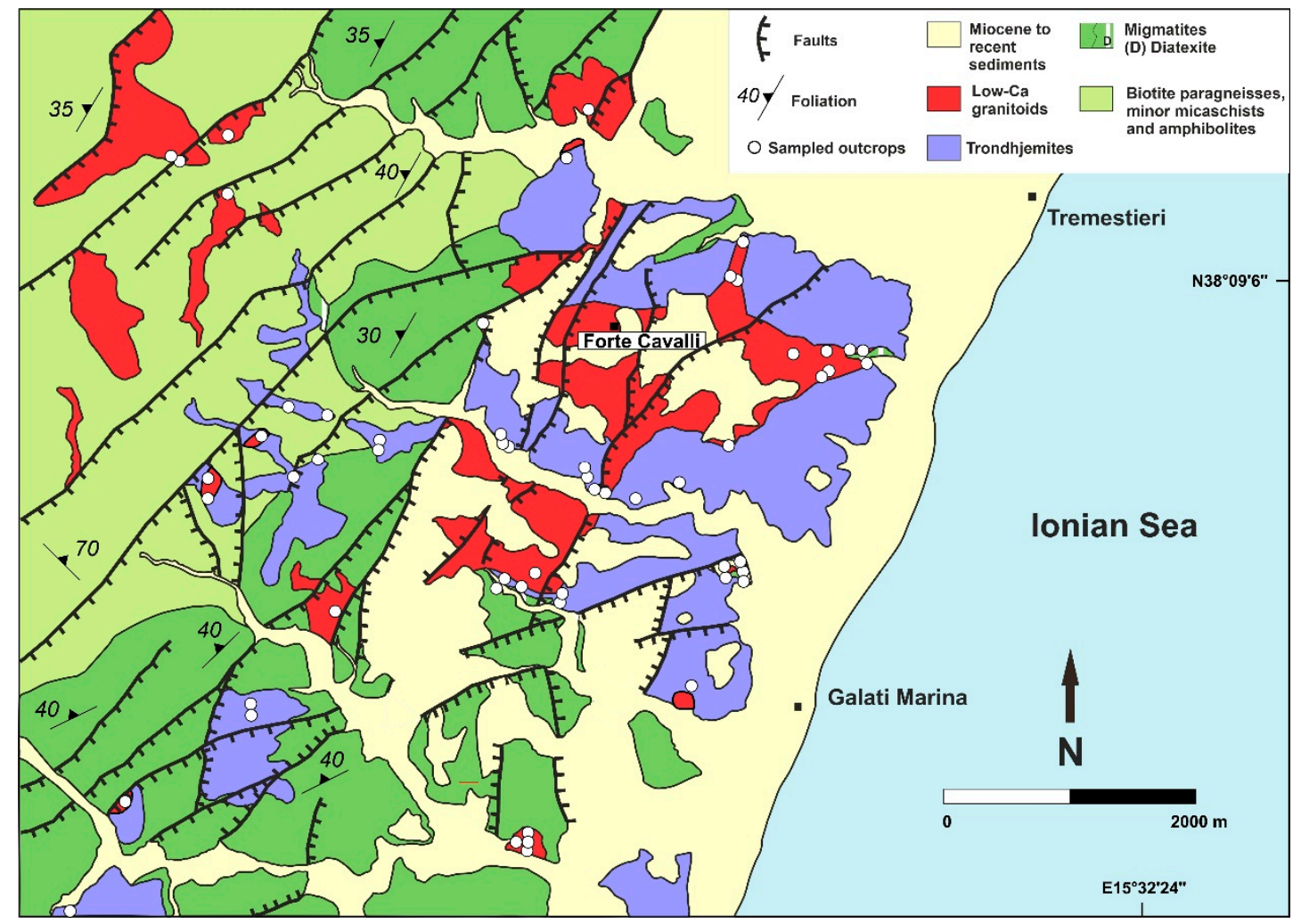

Figure 2. Geological sketch map of the study area, with distribution of the late-Variscan granitoids (modified after [47]; and references therein).

Trondhjemites make up subconcordant to discordant bodies with thickness ranging from a few metres to $\sim 300$ metres (Figure 3a,b). They mainly consist of plagioclase and quartz, with minor biotite $(<0-7 \mathrm{vol} \%)$, muscovite (0-5 vol\%), tartan-twinned K-feldspar (0-5 vol\%), and accessory zircon, apatite, ilmenite and monazite. Common secondary mineral phases produced by deuteric alteration are clinozoisite-epidote s.s., sericite, chlorite and opaques. Texture is mainly hypidiomorphic, coarse- to very coarse-grained and inequigranular (dominant grain-size $>1.5 \mathrm{~cm}$ ), with plagioclase and quartz typically larger than the other mineral phases; plagioclase can occur as crystals up to $4 \mathrm{~cm}$ long (Figure 4a). K-feldspar occurs mostly as medium-sized interstitial patches and thin rims bordering plagioclase crystals. A small amount of myrmekites and metasomatic turbid plagioclase, grown at the expense of primary K-feldspar, locally occur (Figure $4 b$ ). 

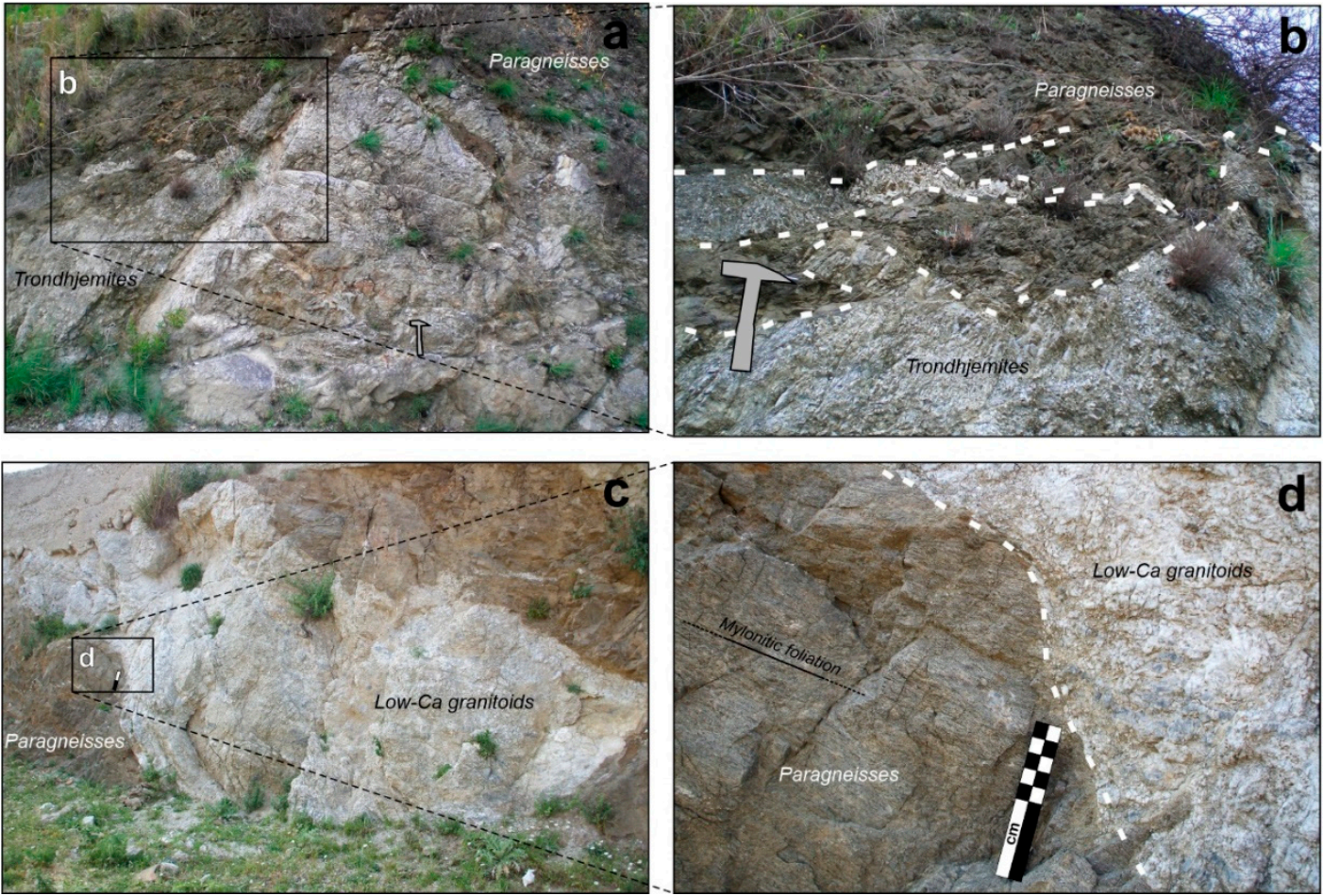

Figure 3. Granitoid-host rock relationships in the Forte Cavalli area. (a) intrusive contacts with, in (b) detail showing a concordant granitoid offshoot folded together with its host paragneiss; (c) intrusive contacts with, in (d) detail of migmatitic foliation cut discordantly by the granitoid rock.

Low-Ca granitoids include granites and low-Ca trondhjemites, cropping out as discordant bodies up to $100 \mathrm{~m}$ thick (Figure $3 \mathrm{c}, \mathrm{d}$ ). Both granitic and trondhjemitic varieties are characterized by a dominant medium to coarse-grained texture (dominant grain-size $<7 \mathrm{~mm}$ ), but inequigranular textures with feldspar megacrysts up to $5 \mathrm{~cm}$ long sometimes occur (Figure $4 \mathrm{c}-\mathrm{f}$ ).

The granites include granites s.s. and alkali feldspar granites, with K-feldspar (either microcline and orthoclase) mainly occurring as medium-coarse-sized subhedral crystals or megacrysts, sometimes intergrown with large quartz. Muscovite (3-6 vol\%, sometimes up to more than $15 \% \mathrm{vol}$ ) is usually more abundant than biotite. Zircon, apatite, monazite, together with rare garnet and andalusite, occur as accessory phases; deuteric phases consist of chlorite, sericite, clinozoisite and opaques. Small amounts of myrmekites and turbid plagioclase replacing microcline, are often present.

Low-Ca trondhjemites, derived from alkali metasomatism of the granites, comprise transitional, low-Ca s.s. and high-Na low-Ca varieties reflecting progressive replacement of magmatic K-feldspar (either microcline and orthoclase) by secondary turbid plagioclase and myrmekites ([47]) (Figure 4e-h). The metasomatic trondhjemites are dominated by plagioclase and quartz, like the magmatic trondhjemites, but have many similarities with the granites, such as the dominant medium-coarse grain size, similar muscovite contents ( $2-6 \mathrm{vol} \%$; up to $15 \mathrm{vol} \%$ ), and the presence of andalusite and garnet among the accessory phases. 

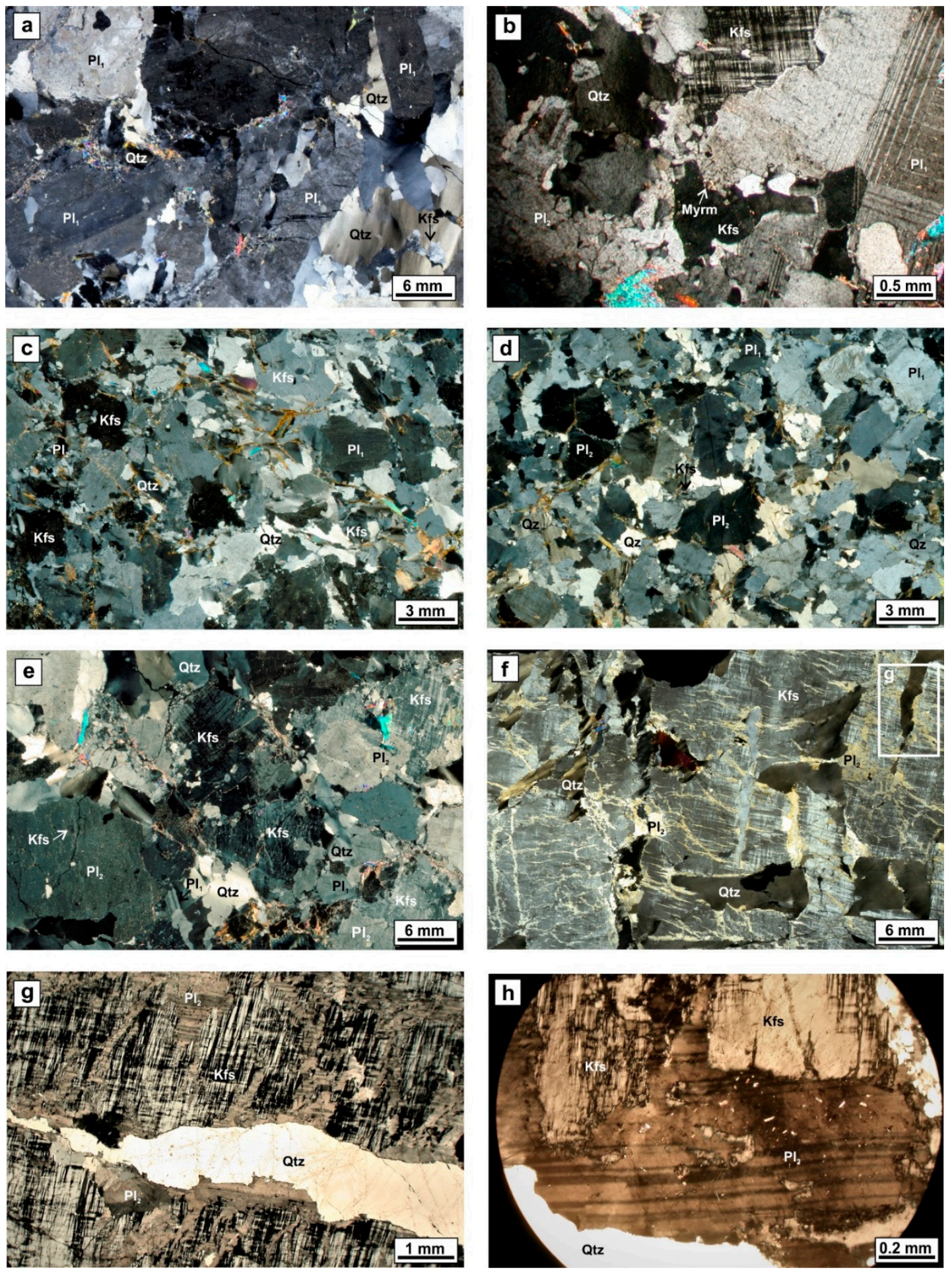

Figure 4. General petrographic features of the studied granitoids (crossed polars). Abbreviations: $\mathrm{Pl}$, plagioclase; Qtz, quartz; Kfs, K-feldspar; Myrm, myrmekite. (a) Thin section scan of a trondhjemite sample showing the typical coarse- to very coarse-grained hypidiomorphic texture, with euhedral to subhedral plagioclase, subhedral micas and anhedral quartz and rare K-feldspar.; (b) Microdomain of trondhjemite sample with interstitial K-feldspar partly replaced by secondary plagioclase $\left(\mathrm{Pl}_{2}\right)$ and myrmekites; (c) Granite sample showing the dominant medium- to coarse grained hypidiomorphic texture with euhedral to subhedral plagioclase, subhedral micas, subhedral-anhedral K-feldspar (mainly 
orthoclase in this sample) and anhedral quartz; (d) Low-Ca (metasomatic) trondhjemite showing the same texture and mineral assemblage of the granite in (c), but with large amount of secondary plagioclase $\left(\mathrm{Pl}_{2}\right)$ formed by metasomatic replacement of the primary K-feldspar; (e) example of the coarse- to very-coarse grained variety of metasomatic trondhjemite with abundant turbid secondary plagioclase replacing large crystals of microcline; (f) very large relic crystal of microcline intergrown with large quartz, preserved in a strongly metasomatized low-Ca granitoid. The image shows early-stage replacement of the microcline by secondary pseudomorphic plagioclase, typically nucleating at the microcline-quartz boundaries or in crystallographic continuity with exsolution perthites; $(\mathbf{g}, \mathbf{h})$ magnifications of $(\mathbf{f})$ showing in detail the pseudomorphic growth of secondary plagioclase which develops magmatic features, such as the Albite polysynthetic twinning, running parallel to the twinning in the replaced microcline; tiny relic islands of microcline are preserved in the magmatic-like $\mathrm{Pl}_{2}$ in (h).

Figure 4c,d are modified after [47].

All the rock types exhibit shear-related deformation microstructures (Figure 5) that will be described in detail in the following section. It is here only highlighted that tectonic grain-size reduction has been considered by [47] to have played a significant role in facilitating fluid infiltration and metasomatic reactions by producing an increase of both the rock permeability and surface-controlled reactivity. Evidence for a link between shearing and metasomatism is provided by common growth of myrmekites and secondary plagioclase along mm-sized shear zones and over sigmoid feldspar porphyroclasts. In particular, in the metasomatic granitoids, the final texture results from the relative number of shear-related microstructures and late to post-shearing crystallization of pseudomorphic secondary plagioclase.
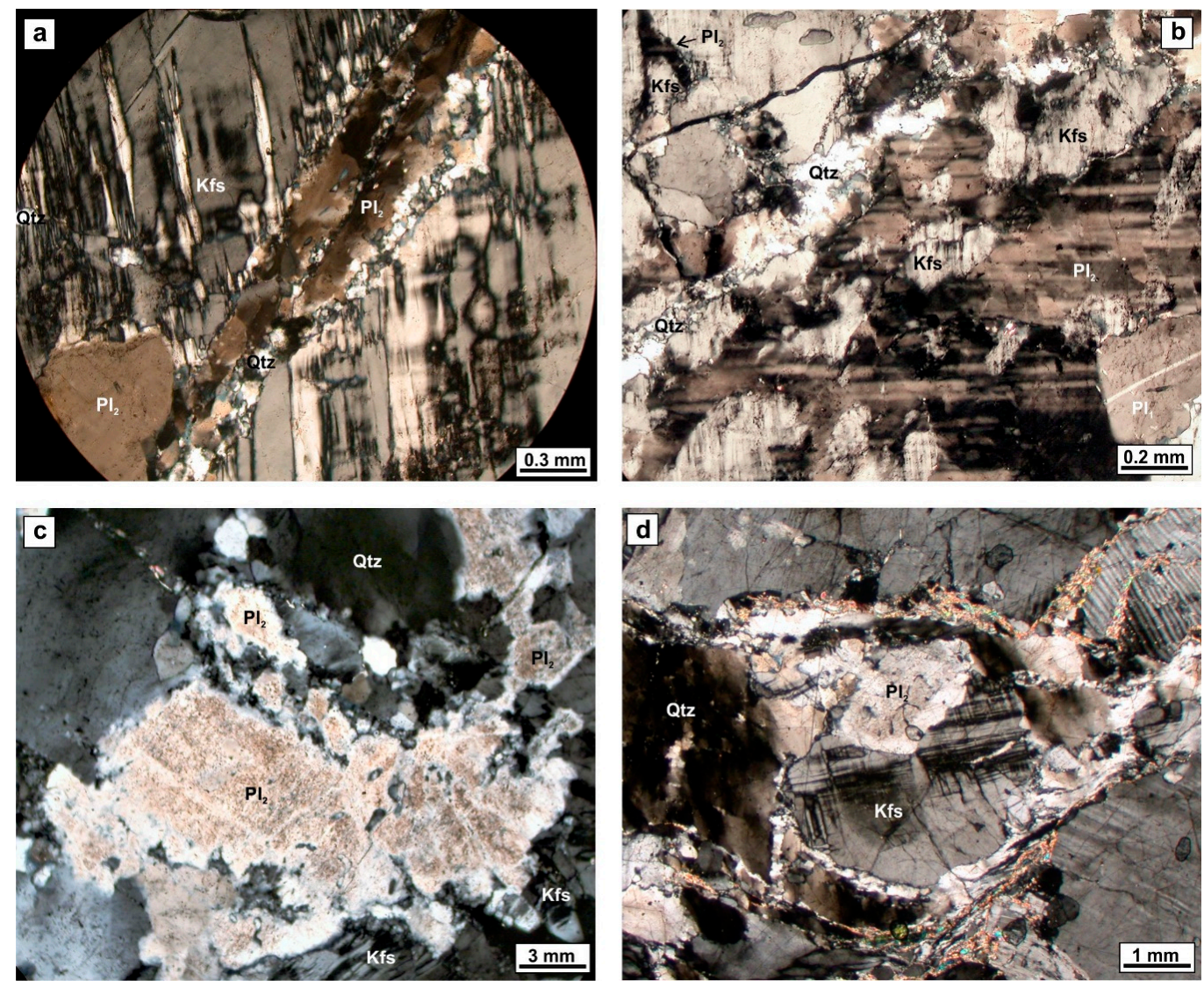

Figure 5. Relationships between shearing and infiltration metasomatism in metasomatic trondhjemites (crossed polars). Abbreviations: Pl, plagioclase; Qtz, quartz; Kfs, K-feldspar. (a-c) growth of secondary plagioclase after grain size reduction in the original granite; (d) growth of myrmekitic plagioclase at expense or relic feldspar porphyroclast. Figure 5a,d are modified after [47]. 


\section{Materials and Methods}

During the field survey, 144 specimens of both magmatic and metamorphic host rocks were collected. In particular, in this paper, we dealt with a set of thirty thin sections over the entire sample collection, which have been selected to study in detail the microstructural features in the two granitoid units of different emplacement ages: trondhjemites (15 samples; c. $310 \mathrm{Ma}$ ) and low-Ca granitoids (15 samples, c. $300 \mathrm{Ma}$ ). We acquired high resolution images of the entire thin sections by using a flatbed scanner (Epson Perfection 3490 Photo) at a resolution of 4800 dpi (both at crossed and parallel polarizers), together with several photomicrographs of deformed domains taken by an Axios Camera mounted on a Zeiss Microscope (model Axioscope 2), both hosted at the Department of Biological, Geological Environmental Sciences, Earth Science Section, University of Catania.

\section{Shear-Related Microstructures}

Studied rocks display a magmatic texture, with euhedral to subhedral micas and plagioclase, subhedral to anhedral K-feldspar and anhedral quartz, that do not define a magmatic foliation.

Nevertheless, all the granitoids exhibit, at different extents, several types of shear-related deformation microstructures (Figures 6-8). Deformation affected all the rocks in the study area $\left(\sim 70 \mathrm{~km}^{2}\right)$ but, in the field, it did not produce thick horizons of intensely sheared rocks. Rather, shear-related mesoscopic structures (e.g., foliation, preferred orientation of minerals) are weakly developed and only discernible at few locations. On the contrary, deformation is more evident at the thin-section scale, and restricted to domains typically forming networks of variously spaced and oriented 'bands' (e.g., Figures 6-8). Protomylonitic structures occur in the most sheared samples from both rock groups (e.g., Figure 6a,b). Recrystallized fine-grained minerals (Qtz, Pl, Wm) in the strain shadows of plagioclase porphyroclasts have been observed (Figure 6i).

In the following two sub-sections we describe in detail shear-related microstructures developed in the two groups of rocks (trondhjemites, emplaced at $\sim 310 \mathrm{Ma}$, and low-Ca granitoids, emplaced at $\sim 300 \mathrm{Ma}$ ), from high-temperature sub-magmatic conditions to progressively lower temperatures.

\subsection{Trondhjemites}

The trondhjemites (Figure 6a,c-e and Figure 7) exhibit clear evidences of deformation at sub-magmatic conditions. The most striking evidence is represented by the widespread occurrence of submagmatic fractures (Figures $6 c$ and $7 a-d$ ), indicating deformation in the presence of melt. These microstructures are typical of rigid or semi-rigid crystal mushes, where a melt fraction still occurs and late magmatic crystals grow in fractures breaking apart early-crystallized minerals (e.g., [91-93]). In the studied rocks, medium- to fine-grained euhedral-subhedral plagioclase and larger interstitial quartz crystallize within veins propagating into large fractured plagioclase (Figures $6 c$ and $7 c, d$ ), consistently with melt migration into dilatation sites. Magma flow within these fractures is further testified by impressive examples of micro-scale filter-pressing (Figure 7c), with mechanical accumulation of plagioclase crystals against narrowing portions of the fracture (Figure 7c), or single euhedral crystals which remained caught in such fracture narrowings during flow of the residual magma (Figure 6c). In Figure $6 \mathrm{c}$ it is interesting to note the occurrence of a second system of submagmatic fractures, (sub-horizontal in Figure 6c), affecting the same plagioclase crystal; the two systems appear to be correlated since they coexist in the same portion of the crystal, whereas the other part of the crystal is fracture-free. The second system is formed by a set of narrow fractures which reveal their submagmatic nature because they are also confined within the plagioclase. 

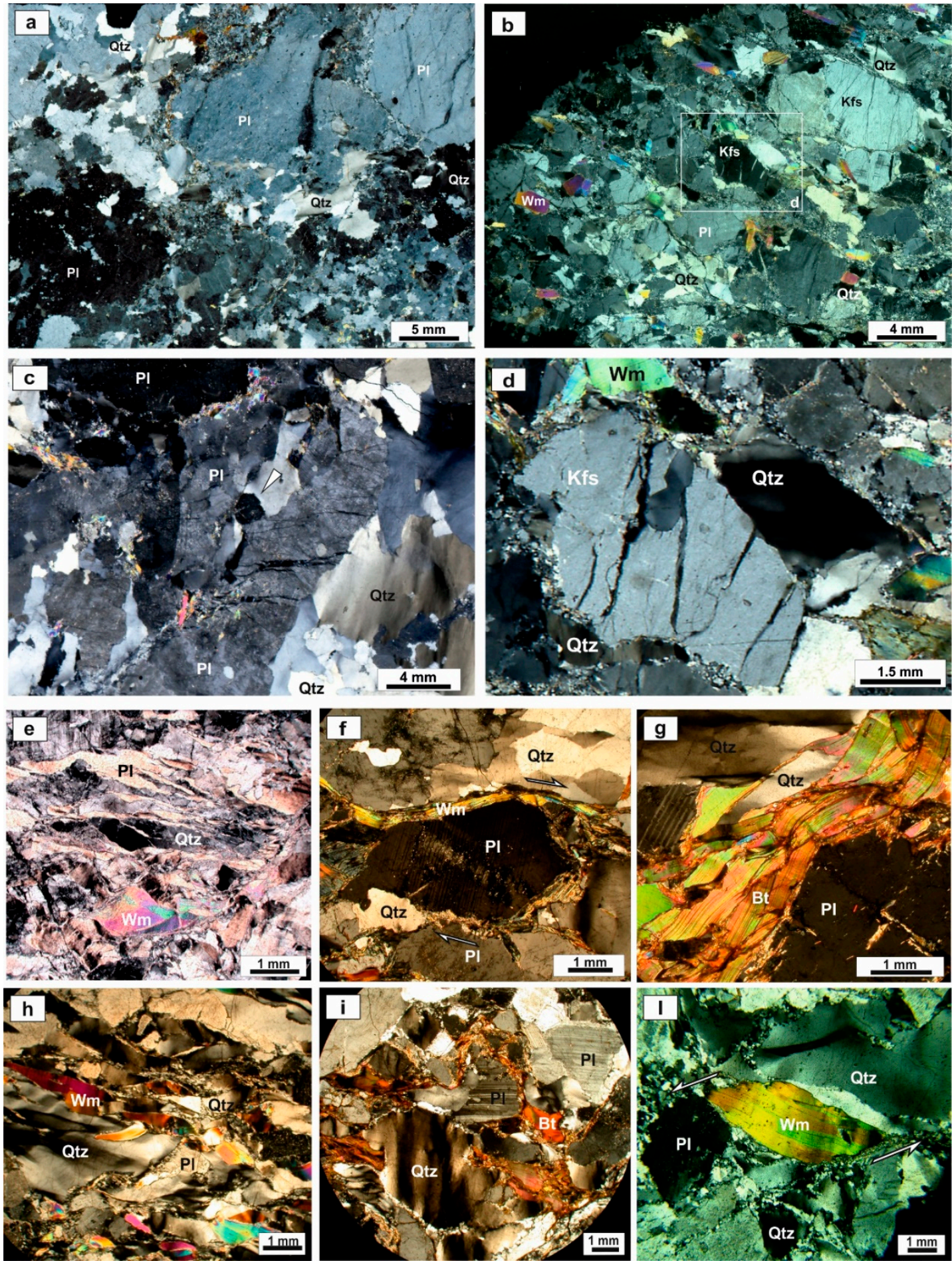

Figure 6. Shear-related microstructures in studied trondhjemites $(\mathbf{a}, \mathbf{c}, \mathbf{e}, \mathbf{f}, \mathbf{g})$ and low-Ca granitoids (b,d,h,i,l) (crossed polars) Abbreviations: Pl, plagioclase; Qtz, quartz; Kfs, K-feldspar; Wm, white mica; Bt, biotite. (a) Protomylonitic texture in trondhjemite sample; (b) protomylonite texture in granite sample; (c) magnification of Figure 4a, illustrating a submagmatic fracture in plagioclase from a trondhjemite sample. The arrow indicates a euhedral plagioclase crystal caught in the narrowing part of the fracture; see the following text for more details; (d) magnification of figure b illustrating a set of submagmatic fractures in K-feldspar filled by quartz; it is possible to observe that the quartz in the two fractures from the right portion of the feldspar crystal is continuous with the quartz outside the feldspar; see the following text for more details; (e) preferred orientation of quartz ribbon, plagioclase 
and muscovite fish-like crystals defining an incipient foliation; (f) asymmetrically anastomosing Bt/Ms folia and $\sigma$-type plagioclase porphyroclast indicating a dextral shear-sense; (g) micaceous layer and elongated quartz grains defining a foliation deflected around a plagioclase porphyroclasts; (h) aligned stretched quartz grains and white mica flakes forming a mylonitic foliation (embryonal S-C foliation pattern indicating a dextral shear sense); (i) large sigmoidal quartz clast with biotite tails indicating a sinistral sense of shear; (l) fish-shaped white mica suggesting a sinistral sense of shear.

Deformation at submagmatic conditions is also supported by chessboard pattern extinctions in quartz (Figure 7d,e) [94], resulting from combined activation of basal $<\mathrm{a}>$ and prism $<\mathrm{c}>$ slip systems, which is mostly referred to occur at $\mathrm{T}$ above $650{ }^{\circ} \mathrm{C}$ for pressure up to $1.0 \mathrm{GPa}$ [95-98].

Evidences of solid state-high temperature (HT-Ss) deformation come from grain boundary migration (GBM) recrystallisation [95-97,99,100] of quartz crystals $\left(500-700{ }^{\circ} \mathrm{C}\right.$; [98]) with examples of inequigranular grain size and interlobate and sutured crystals boundaries, where the new forming grains tend to obliterate the neighbour ones (Figure 7h). Ribbon-like quartz crystals with undulose extinction, showing elongation parallel to the preferred stretching direction, occur locally (Figure 7g,h). Quartz and plagioclase crystals with irregular and lobate boundaries, as a result of bulging (BLG) recrystallisation, indicate sub-solidus deformation at $450-600{ }^{\circ} \mathrm{C}$ ([98]; Figure 7f). Few examples of myrmekitic intergrowths may also indicate deformation at high- to medium- temperatures. Lower temperature sub-grain rotation (SGR) recrystallisation [95-101] occurs locally as oriented polycrystalline quartz aggregates (Figure $7 \mathrm{~h}$ ) indicating deformation temperatures of $400-500{ }^{\circ} \mathrm{C}$ [98]. Rarely, quartz forms a core-and-mantle structure.

Bulging and impingements of plagioclase porphyroclasts with quartz grains (Figures $6 \mathrm{f}$ and $7 \mathrm{f}$ ) suggest deformation temperatures between $500{ }^{\circ} \mathrm{C}$ and $700^{\circ} \mathrm{C}[63,65]$. Core and mantle microstructures, typical of HT solid-state deformation, are also quite diffuse (Figure 7i). Very-fine grained quartz, and subordinately plagioclase, recrystallize at the boundaries of large plagioclase porphyroclasts. A temperature of deformation ranging between 400 and $500{ }^{\circ} \mathrm{C}$ is mainly indicated by deformed polysynthetic albite twins in plagioclase and, in rare cases, by eye-catching examples of kink-folded crystals (Figure 7m). Sometimes, in the rare K-feldspar crystals deformation twins also occur. Bulging (BLG) recrystallization of quartz crystals $[95,98]$ indicates for these rocks temperature of deformation under $400{ }^{\circ} \mathrm{C}$ (Figure 7i). Other microstructures here observed developed probably below $450{ }^{\circ} \mathrm{C}$ [98], mainly consisting of undulose extinction of quartz (Figure 7g,i), mica kink banding (Figure 7l), feldspar bending and fracturing (Figure $7 \mathrm{~d}, \mathrm{f}, \mathrm{m}$ ); subgrains and new grains characterizing recrystallization domains in quartz and feldspars have also been observed (Figure 7i).

Evidences of late cataclastic-flow have been also observed, consisting of $\mathrm{mm}$-thick conjugate sets of cataclastic shear bands, with fragmented quartz and feldspar grains (Figure 7a-d). 

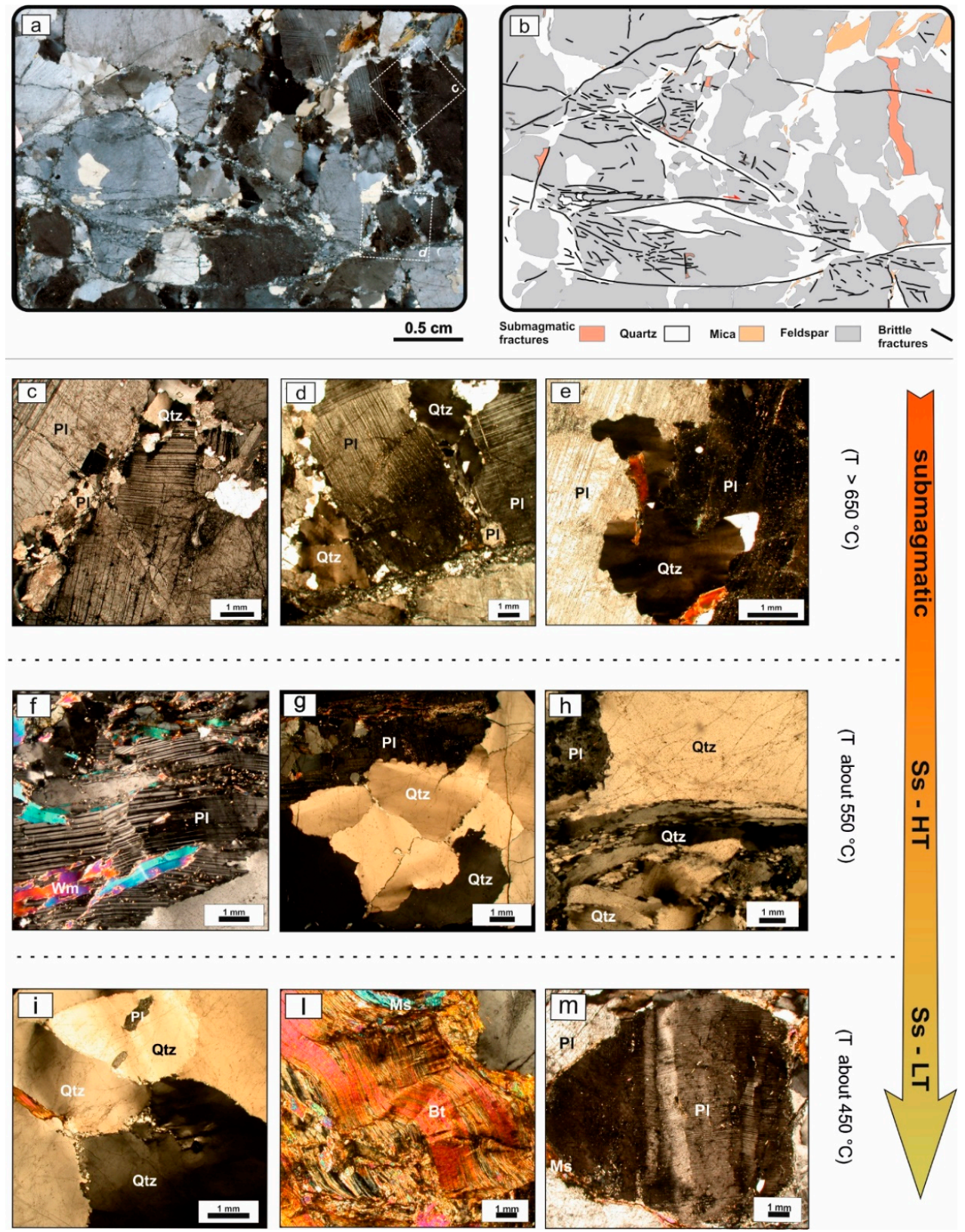

Figure 7. Shear-related deformation microstructures developed in the trondhjemites from sub-magmatic to low-temperature subsolidus conditions (Ss-HT = Solid state High Temperature; Ss-LT = Solid state Low Temperature) (crossed polars). Abbreviations: Pl, plagioclase; Qtz, quartz; Kfs, K-feldspar; Wm, white mica; Bt, biotite. (a) thin section scan of a representative trondhjemite specimen; (b) microtectonic sketch drawing of (a); (c) submagmatic fracture (please see 'a' for location within the thin section) filled by quartz dislocating a large feldspar grain showing internal plastic deformation given by twinning; (d) gently left-dipping cataclastic band crosscutting sub-vertical submagmatic vein (please see 'a' for location in the thin section); (e) chessboard pattern in quartz grain in contact with plagioclase showing lobate grain boundaries; (f) white mica and plagioclase grains intensely deformed; (g) recrystallization subgrains (SGR) and bulging (BLG) at the edge of a stretched quartz grain showing undulose extinction; (h) ribbon-like quartz showing undulose extinction; (i) quartz subgrains at the boundaries of intensely deformed large grains with undulose extinction; (1) pervasive kink bands in micaceous layers; (m) twins planes bent in plagioclase. 


\subsection{Low-Ca Granitoids}

The rocks belonging to the second suite of granitoids, consisting of granites and metasomatic trondhjemites with the same low-Ca amount (dated at $300 \mathrm{Ma}$ [48-50], Figure 8), also show microstructures typically associated to submagmatic conditions, as well as to solid state deformation, from high- to lowtemperature conditions.

High-temperature deformation microstructures, such as submagmatic fractures (Figures $6 \mathrm{~d}$ and $8 \mathrm{a}-\mathrm{d}$ ) and quartz chessboard pattern (Figure 8e,m), are also frequent in these granitoids.

Submagmatic fractures affect large K-feldspar and plagioclase crystals. It is, however, to be highlighted that, also in the case of fractures, apparently cutting the secondary plagioclase, the fractures affected the feldspar when it was still a magmatic K-feldspar. This is illustrated in Figure $4 \mathrm{f}-\mathrm{h}$, where the interfaces between the original K-feldspar and the quartz veins acted as a preferential path for the fluids involved in the metasomatic crystallization of the pseudomorphic secondary plagioclase.

Another aspect to highlight is that, in the low-Ca granitoids, quartz is the sole mineral phase filling the fractures. In this case the submagmatic nature of the fractures is only testified by the continuity between the quartz in the vein and the large quartz patches surrounding the feldspar, demonstrating that all the quartz crystallized at the same stage from the residual melt. In the same rocks there are many examples of other types of quartz-filled fractures that are instead clearly post-magmatic since they cross indistinctly all the mineral phases, including quartz (Figure 8f).

Evidences of solid state high-temperature deformation $\left(\mathrm{T}>530{ }^{\circ} \mathrm{C}\right)$ are provided by quartz grain boundary migration (GBM) recrystallisation [95,97], as frequent as in the trondhjemites, and indicating temperature of deformation between $500^{\circ} \mathrm{C}$ and $700{ }^{\circ} \mathrm{C}$ ([98]; Figure $\left.8 \mathrm{~g}\right)$. At deformation temperatures between $450{ }^{\circ} \mathrm{C}$ and $600{ }^{\circ} \mathrm{C}$ [63] dislocation climb becomes possible in plagioclase and recrystallisation starts to be important, occurring mainly by BLG (Figure 8d,g). Subgrain rotation recrystallisation $[95,101]$ occurs in quartz crystals, where old grains are partially replaced by new forming ones, suggesting temperature of deformation of $\sim 500{ }^{\circ} \mathrm{C}$ [98] (Figure 8f). Finally, small dynamic recrystallised quartz grains around older quartz cores or plagioclase porphyroclasts forming core-and-mantle structures, are common in this suite of rocks (Figure 8h-l).

Subsolidus low-temperature conditions are dominantly represented by deformation twins in plagioclase, and in a few cases, in K-feldspar, which according to [98], they typically occur between $400{ }^{\circ} \mathrm{C}$ and $500{ }^{\circ} \mathrm{C}$ (Figure $8 \mathrm{~m}$ ). Deformation microstructures developed under relatively lower temperature $\left(\sim 400{ }^{\circ} \mathrm{C}\right)$ mostly consist of mica fish and stretched andalusite (Figure $\left.8 \mathbf{i}\right)$, as well as kinking of micas (Figure 81). Quartz shows lobate and sutured grain-boundaries due to bulging, indicating deformation at temperature of $\sim 300-400{ }^{\circ} \mathrm{C}$ (Figure $8 \mathrm{~m}$ ), even if it is less frequent than in trondhjemites. Ribbon-like quartz is also frequent, defining a clear micro-scale anisotropy for these rocks (Figure 6b,h and Figure $8 \mathrm{~h}$ ). The occasional presence of subgrains elongated subparallel with respect to a preferred stretching direction suggests that deformation protracted during cooling. Plagioclase shows intracrystalline plastic deformation evidenced by twin planes bending (Figure 8m). Undulose extinction, as well as deformation bands, occur frequently in quartz grains (Figure 81), pointing to deformation at temperature under $300{ }^{\circ} \mathrm{C}$ [98]. Mica fish (Figure 61) and kink bands indicate intracrystalline plastic deformation (Figure 8i-1). Later, brittle fracturing occurred at lower temperatures $\left(\mathrm{T}<\sim 250^{\circ} \mathrm{C}\right.$; [98]). Rare examples of tectonic grain size reduction by cataclastic flow are usually confined to narrow shear bands. 

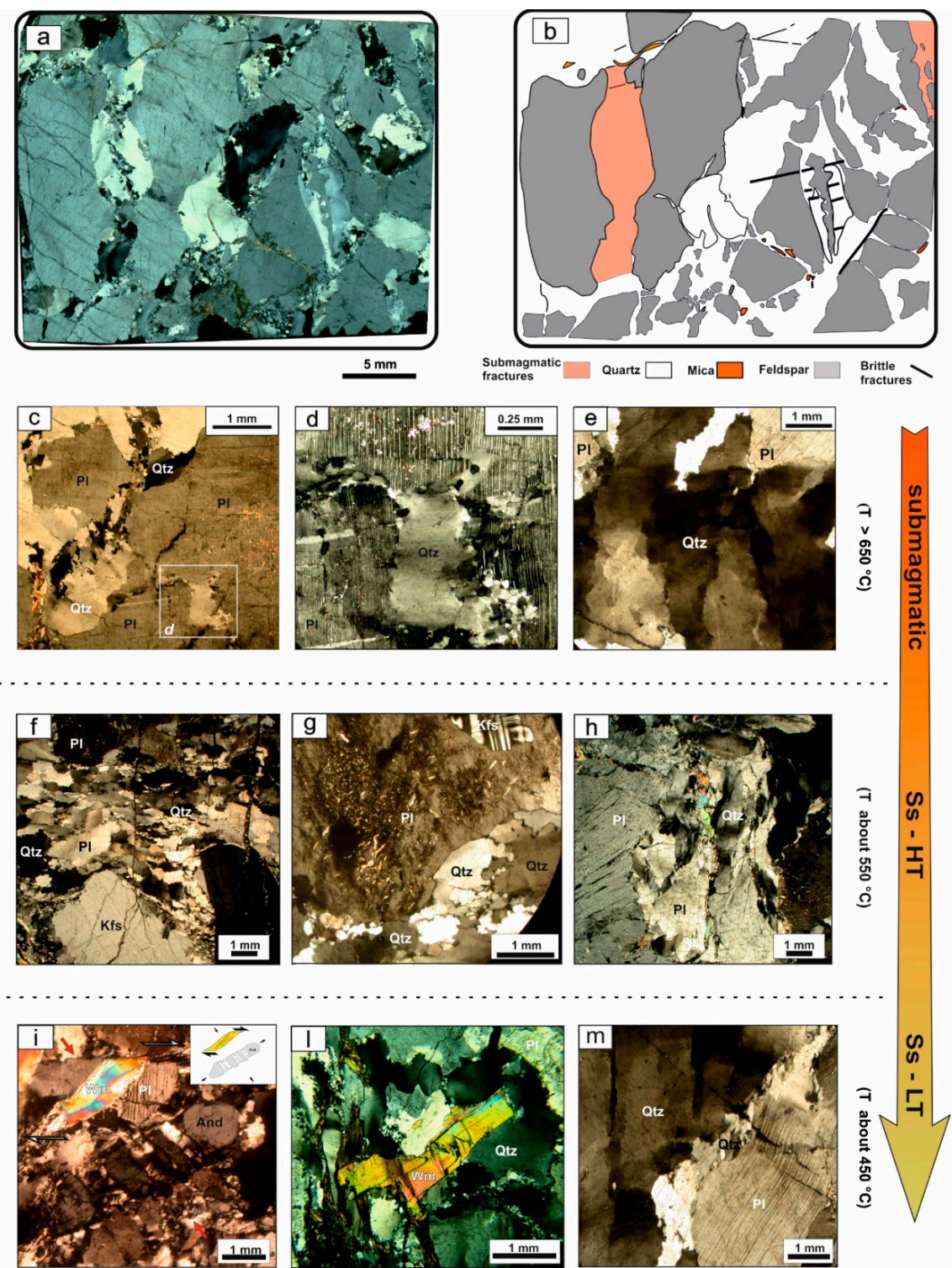

Figure 8. Shear-related deformation microstructures developed from sub-magmatic to low-temperature subsolidus conditions in the low-Ca granitoids (Ss-HT = Solid state High Temperature; Ss-LT = Solid state Low Temperature) (crossed polars) Abbreviations: Pl, plagioclase; Qtz, quartz; Kfs, K-feldspar; Wm, white mica; Bt, biotite; And, andalusite. (a) thin section scan of a representative a low-Ca specimen; (b) microtectonic sketch drawing of (a); (c) submagmatic fracture filled with quartz in plagioclase; (d) detail of quartz vein shown in c showing a lobate grain boundary between plagioclase and quartz, the latter showing subgrains as well as undulose extinction, due to subsequent deformation; (e) Chessboard pattern extinction in quartz; quartz sub-grain rotation recrystallization (SGR) microstructure also occur in the top left corner of the image; (f) subgrain rotation (SGR) associated with grain boundary migration recrystallization (GBM) at the edges of quartz relic grains; subvertical fractures dismembering feldspar grains also occur; (g) quartz domain with GBM and SGR; (h) stretched quartz grains showing ribbon-like shape, kinked plats of mica, and bended plagioclase twin planes; (i) two coupled kinematic indicators, given by mica-fish and boudinaged andalusite grain suggesting a dextral sense of shear ( $\sigma_{1}$ orientation is given by red arrows; see sketch in the inset for interpretation); (1) highly deformed mica in the centre of picture shows intense bending of (001) planes, whereas larger quartz grains show core-and-mantle structures together with bulging; (m) thin quartz-rich domain developed at the edge of a quartz grain with chessboard extinction pattern, that shows recrystallization of subgrains defining an oblique foliation near the border of the adjacent plagioclase grain. 


\section{Discussion}

\subsection{A Late-Variscan Shear Zone in the Peloritani Mountains}

Until now, only Alpine shear zones had been well-constrained in the Aspromonte Unit from Peloritani Mountains and Aspromonte Massif, associated first to early-Alpine subduction and then to late-Alpine exhumation $[26,27,29,34]$. Alpine mylonitic events in the region took place in a compressional regime and the whole orogenic cycle developed up to upper amphibolite facies, but entirely subsolidus, conditions ([51]; and references therein). In particular, Alpine shearing mostly produced LT deformation microstructures $\left(\mathrm{T} \leq 450^{\circ} \mathrm{C}\right)$, and an evident Alpin foliation developed along the tectonic contacts between the Mandanici and Aspromonte Units ([26]; and references therein) (Figure 1). Peak metamorphic conditions of $\sim 0.8 \mathrm{GPa}$ at $\sim 600{ }^{\circ} \mathrm{C}[26,29]$ and the development of an evident Alpine foliation were only attained at the above tectonic contacts and in a small area northwest of Messina ([90] and references therein), many $\mathrm{km}$ apart from the study area.

Conversely, non-coaxial deformation microstructures detected in this study in late-Variscan cooling granitoids provide, for the first time, evidence for a late-Variscan shear phase in the Peloritani Mountains.

The occurrence of rare micro-boudins affecting mm-sized andalusite crystals in the studied low-Ca granitoids (Figure 8i) might indicate a general extension-type deformation. This finding is consistent with the occurrence of stretched and pinch-and-swell garnet porphyroclasts in phyllites from the central Peloritani Mountains [46], leading those authors to tentatively suggest a late- to post-orogenic shearing stage related to late-Variscan exhumation.

Finally, the observed gradual transition from submagmatic to low-temperature subsolidus microstructures, developed at progressively decreasing temperatures, points to a continuous change in the deformation mechanisms during cooling of the granitoids (e.g., [19,95,102,103]). Although an Alpine overprint might have been superimposed on the Variscan microstructures, all the above exposed arguments are reasonably in favor of a continuous evolution of late-Variscan shearing. This shearing involved the granitoid bodies at suprasolidus conditions, as documented by the widespread occurrence, in both groups of studied granitoids, of typical submagmatic deformation microstructures such as chessboard extinction in quartz and submagmatic fractures (Figure 7). In this respect, it is to be remarked that chessboard subgrain pattern in quartz have been alternatively considered to reflect deformation at submagmatic (e.g., [92,102-107]) or HT subsolidus (e.g., [19,99,108-110]) conditions. Nevertheless, independently from their suprasolidus vs. subsolidus categorization of the chessboard pattern, most researchers agree that this microstructure indicates deformation at $\mathrm{T}>650{ }^{\circ} \mathrm{C}$, which typically correspond to melt-present conditions in a crystallising felsic granitoid system (e.g., Figure 3 in [91]).

In addition, several examples of submagmatic veins provide a direct evidence of deformation in presence of melt, therefore clearly indicating that the shear zone was active, in the Aspromonte-Peloritani sector of the CPO, during late-stage crystallization of the late-Variscan granitoid magmas.

It is thus possible to trace a spatial connection and a temporal continuity with the activation of the crustal-scale shear zone, evolving from deep-seated to upper crustal conditions, which controlled the emplacement of the granitoid magmas of the $13 \mathrm{~km}$-thick Serre Batholith, in central Calabria, between $\sim 297$ and 292 Ma ([15,36,38,42,77,111,112]; and references therein). Syn-shearing crystallization of late-Variscan granitoids ( 304-300 Ma; [48]) has been also ascertained for the Sila Batholith, in northern Calabria, where continuous shear-related deformation from magmatic to low-temperature solid state conditions has been documented by $[39,40,43,44]$.

At a larger continental scale [51], in agreement with [54,55], proposed that the formation of the Sila and Serre Batholith in northern and central Calabria could be framed in the activity of East Variscan Shear Zone (EVSZ) [52-55].

The EVSZ is a branch of a complex network of coeval strike-slip shear zones, [54,55,113-117], which were involved in the final assembly of Pangea, up to around $300 \mathrm{Ma}$, in regions of oblique collision of Gondwana, Gondwana-derived microcontinents and Laurussia [118-120]. In particular, the EVSZ has been mostly described as a dextral transpressive shear zone running from the external massifs 
of the Alps to the Corsica-Sardinia-Maures-Tanneron Massifs [53,121-123]. Padovano et al. [54,55] have recently proposed that also the Northern Apennines and the CPO were involved in the EVSZ, and that all these regional shear zones were characterized by a transpressional and/or transtensional kinematics, associated with exhumation of deep-middle crust and syntectonic granitoid emplacement.

The late-Variscan shear zones from the Sila and Serre Massif of northern and central Calabria are long known, whereas the proposition from $[54,55]$ that also Peloritani Mountains could be involved in the EVSZ was based on the late-Variscan Ar-Ar muscovite age of $301 \pm 2$ Ma obtained for a mylonitic augen gneiss by [45]. The latter authors proposed indeed that the age of $301 \pm 2 \mathrm{Ma}$ was associated with mylonitisation during thrusting of the Aspromonte Unit over the Mandanici Unit. Nevertheless, the contact between the two units is marked by a $30 \mathrm{~m}$-thick cataclastic to mylonitic shear zone that also involves Triassic to Cretaceous greenschist-facies metasediments from the original cover of the Mandanici Unit ([124]; and references therein), therefore demonstrating the Alpine age of that shear zone. In fact, the age of $\sim 300 \mathrm{Ma}$ in the mylonitic augen gneisses cannot be univocally ascribed to a shearing phase, because it corresponds to the age of the thermal peak of the Variscan metamorphism in the CPO, which is recurrently recorded in both sheared and unsheared rocks (e.g., [48,90,125,126]).

On the other hand, shear-related deformation microstructures in the presence of late-Variscan melt found for the first time in this study are a clear evidence of late-Variscan shearing, and might therefore better support the hypothesis that the Peloritani Mountains were also possibly involved in the EVSZ.

In this respect, it is interesting to note that [51] suggested a different location of the CPO massifs with respect to strike-slip domains developed in the last stages of the EVSZ activity, based on the distribution of the late-Variscan magmatic products. In particular, by considering the observed strict connection between activation of late-Variscan shear zones and emplacement of large syn-shear granitoid complexes along the EVSZ, the presence of only small anatectic plutons, rather than composite batholiths, in the Aspromonte-Peloritani has been tentatively considered related to their more peripheral position in the shear zone system.

This suggestion appears now consistent with the style of deformation observed in the granitoids from the Peloritani Mountains which do not form thick horizons of strongly foliated rocks, like the syn-tectonic Serre and Sila granitoids, but are instead characterized by less pervasively sheared rocks.

Another aspect to be considered is the age of the recorded shearing events in NE Sicily, with reference to those recorded in different segments of the EVSZ. ([122] and references therein) remark indeed that the EVSZ is a network of interconnected shear zones that developed progressively according to a tectonic linkage model in the time interval of about 335-300 Ma.

The end of late-Variscan shearing in the CPO can be set between $292 \mathrm{Ma}$, which is the age of weakly deformed upper crustal granodiorites from the Serre Massif $[15,127]$ and the age, similar within error, of $281 \pm 8 \mathrm{Ma}$ of undeformed felsic dykes intruding the sheared granitoids of the Sila Batholith [44].

On the other hand the oldest dated syn-shear magmatic rocks in the CPO are the studied trondhjemites from the Peloritani Mountains, emplaced at $310 \mathrm{Ma}$ [49,50], that indicate it as the minimum age for initiation of the shear zone activity. Rb-Sr Bt cooling ages $[48,128]$ together with thermobaric modelling [112] suggest that the granitoids emplaced into the upper crust of Aspromonte-Peloritani and Serre areas took more than $\sim 10 \mathrm{Ma}$ to cool at a $\mathrm{T}$ of $\sim 300^{\circ} \mathrm{C}$; this would indicate that deformation in the $\sim 300 \mathrm{Ma}$ low-Ca granitoids lasted until $\sim 290 \mathrm{Ma}$, indicating a total duration of the shear zone event of $\sim 20 \mathrm{Ma}$, from intrusion of the trondhjemites at $\sim 310 \mathrm{Ma}$ to LT subsolidus deformation in the $\sim 300$ Ma granites. 


\subsection{Supra- to Sub-Solidus Deformation in Granitoids Cooling at Middle to Upper Crustal Depth}

Deformation microstructures developed from a submagmatic to low-temperature solid-state regime in trondhjemites and granites from the Peloritani Mountains give the opportunity to investigate the relationships between fabric development and syn-tectonic cooling of granitoids emplaced at middle to upper crustal conditions. Changing temperatures during prograde or retrograde orogenic evolution are largely considered to exert the main role influencing the mechanisms of deformation in crustal rocks (e.g., [98,129]). Nevertheless, other factors can also affect the rheological behaviour of the crust, such as the rock composition and grain size, the limiting pressure, the strain rate, the flow vorticity, and the presence of a fluid or a melt phase [130,131].

In the Peloritani Mountains, two continuous sequences of shear-related deformation at submagmatic to low-temperature subsolidus conditions developed during cooling of granitoids emplaced at different times and different depth. The two granitoid intrusions have a similar composition from a rheological point of view, having the same silica content [47] and being composed by comparable amounts of quartz, feldspars and micas. Furthermore, evidences of deformation in the presence of melt occur in both granitoids. The main difference between them is that the grain size is dominantly coarse to very-coarse in the trondhjemites and medium to coarse in the younger low-Ca granitoids. We do not have information about the strain rate and the flow vorticity and, therefore, the factors that we take into account in addition to temperature, to assess their possible role in controlling the development of specific deformation mechanisms in a natural shear zone, are the grain size and the confining pressure.

In this latter respect, precise pressure condition estimates are not available for the Peloritani Mountains granitoids, also due to the lack of suitable mineral assemblages but, according to [47] and [65], the $\sim 310 \mathrm{Ma}$ trondhjemite magmas intruded the migmatite host rocks after leucosome solidification and migmatite equilibration at $\sim 0.5 \mathrm{GPa}$ (i.e., $\sim 14 \mathrm{~km}$ ) (e.g., [69,70]). On the other hand, final crystallization of the $\sim 300 \mathrm{Ma}$ granites is likely to have occurred at upper crustal levels, at a pressure of $\sim 0.3 \mathrm{GPa}$ (i.e., $\sim 8 \mathrm{~km}$ ), as suggested by the occurrence of local granophyric and graphic textures, which are typically associated to crystallization under strong undercooling conditions (e.g., [132,133]). Low-pressure crystallization of the granitic magmas is also supported by the occasional presence of magmatic andalusite in the studied low-Ca granitoid rocks. It is therefore interesting to compare the different types of diagnostic deformation microstructures developed in the trondhjemites, that were intruded at deeper crustal levels $(\sim 14 \mathrm{~km})$ during the early evolution of the shear zone and in the granites that were intruded $10 \mathrm{Ma}$ later at shallow depth $(\sim 8 \mathrm{~km})$.

Comparison between the two granitoid associations shows similar sequences of deformation microstructures, developed at progressively lower temperatures, that indicate continuous shear zone activity during cooling of the granitoids.

Unlike the syn-tectonic tonalites and granodiorites of the Serre and Sila batholiths, both Pelolritani Mountains trondhjemites and granites do no show a pre-full crystallization [134], or magmatic fabric [108]. This fabric indicates a free rotation of the crystals in the magma, with a melt fraction greater than $\sim 40 \%$ (e.g., [108]). The absence of magmatic fabrics in the trondhjemites would indicate that shearing probably started soon after the emplacement of the trondhjemitic magmas. This would imply, in turn, that magma emplacement assisted the nucleation of the shear zone in the study area, (e.g., [10,135]).

Neves et al. [135] (and references therein) have indeed suggested that nucleation of shear zones in crystallizing plutons is a plausible mechanism, due to marked reduction of the effective viscosity in melt-bearing rocks, even at low melt fractions $(<10-20 \%)$, compared to melt-free rocks, that could therefore favor strain localization in these weak domains. 
Activation of early shear zone domains in the trondhjemite plutons according to these considerations is, however, at odds with the lack of magmatic fabrics also in the granites, that were emplaced when the shear zone was already operating in the area for several million years. On the other hand, the recurring spatial association of "old" trondhjemites and "young" granites throughout the Peloritani Mountains and Aspromonte Massif, as visible in Figure 1, suggests that the ascent pathways used by the trondhjemite magmas were then re-used by the granites.

Furthermore, for both types of granitoid plutons, a similar tight connection between emplacement and tectonics, is suggested by the elongation of the plutons along the same trends, which is especially evident in the Aspromonte Massif (e.g., E-W elongated Punta d'Atò pluton; [34]).

In this respect, the absence of a pre-full crystallization fabric in the granites might indicate that the granite magmas were emplaced by reusing the ascent pathways of the trondhjemites during a phase of tectonic quiescence. Shearing in the Peloritani-Aspromonte sector of the $\mathrm{CPO}$ then resumed, at a time when those granites were largely crystallized, and the main shear zones of the CPO started to operate in central and northern Calabria, leading to syn-tectonic construction of the Serre and Sila batholiths and to associated 13-km displacement of deep-crustal gneisses, that were finally exhumed to shallow upper crustal levels at 290 Ma (e.g., Mammola paragneisses [15,41,111,136]).

An alternative explanation is that also the peloritanian granitoid magmas were emplaced syntectonically, but the magmatic fabric was obliterated by subsequent deformation, possibly already at near solidus conditions, involving differential grain rotation, grain interference, and grain fracturing ([108]; and references therein).

Despite the apparent lack of magmatic fabrics in the studied trondhjemites and low-Ca granitoids from the Peloritani Mountains, quartz chessboard extinction and, especially, submagmatic fractures, indicate that deformation started anyway in the presence of melt. In particular, submagmatic fractures are considered to reflect deformation at low melt fractions $<0.4$ and, more typically, within the $0.3-0.1$ range (e.g., [91,103,137]).

A fundamental aspect to be considered is that both granitoid units share the same sequence of fabrics developed from submagmatic to low temperature subsolidus conditions (Figure 9). This implies overprinting of low temperature microstructures on earlier submagmatic and HT subsolidus relics, making difficult to establish the relative role of the different deformation mechanisms in the two granitoid units and their relative implications. Nevertheless, some significant inferences can be drawn by estimating the incidence of each recorded deformation microstructure in both units.

By first reviewing the microstructures typical of submagmatic conditions observed in the two granitoid units, common and distinctive features can be observed. Submagmatic fractures in feldspars and chessboard patterns in quartz are quite equally distributed in the two groups of rocks, suggesting that the larger grain size of the trondhjemites, or the relatively greater emplacement depth, did not make them particularly prone to fracture or deform at low melt fractions.

Most of the SS-HT deformation microstructures, such as feldspar bulging, sub-grain rotation dynamic recrystallization, and grain-boundary migration also have a similar distribution in the two granitoid types of rocks.

Similarly, ribbon-like quartz is largely represented in all the granitoid types, as well as quartz grain boundary migration and subgrain rotation. In contrast, core and mantle structures of quartz grains are distinctly more frequent in low-Ca granitoids than in the trondhjemites. This diversity might reflect the significant grain-size difference in the two rock types, due to the higher amount of grain boundaries per volume unit in the finer-grained low-Ca granitoids.

Regarding the SS-LT microstructures, no significant difference has been detected in the two granitoid units in terms of incidence of both quartz bulging, plagioclase deformation twinning and mica kinking. 

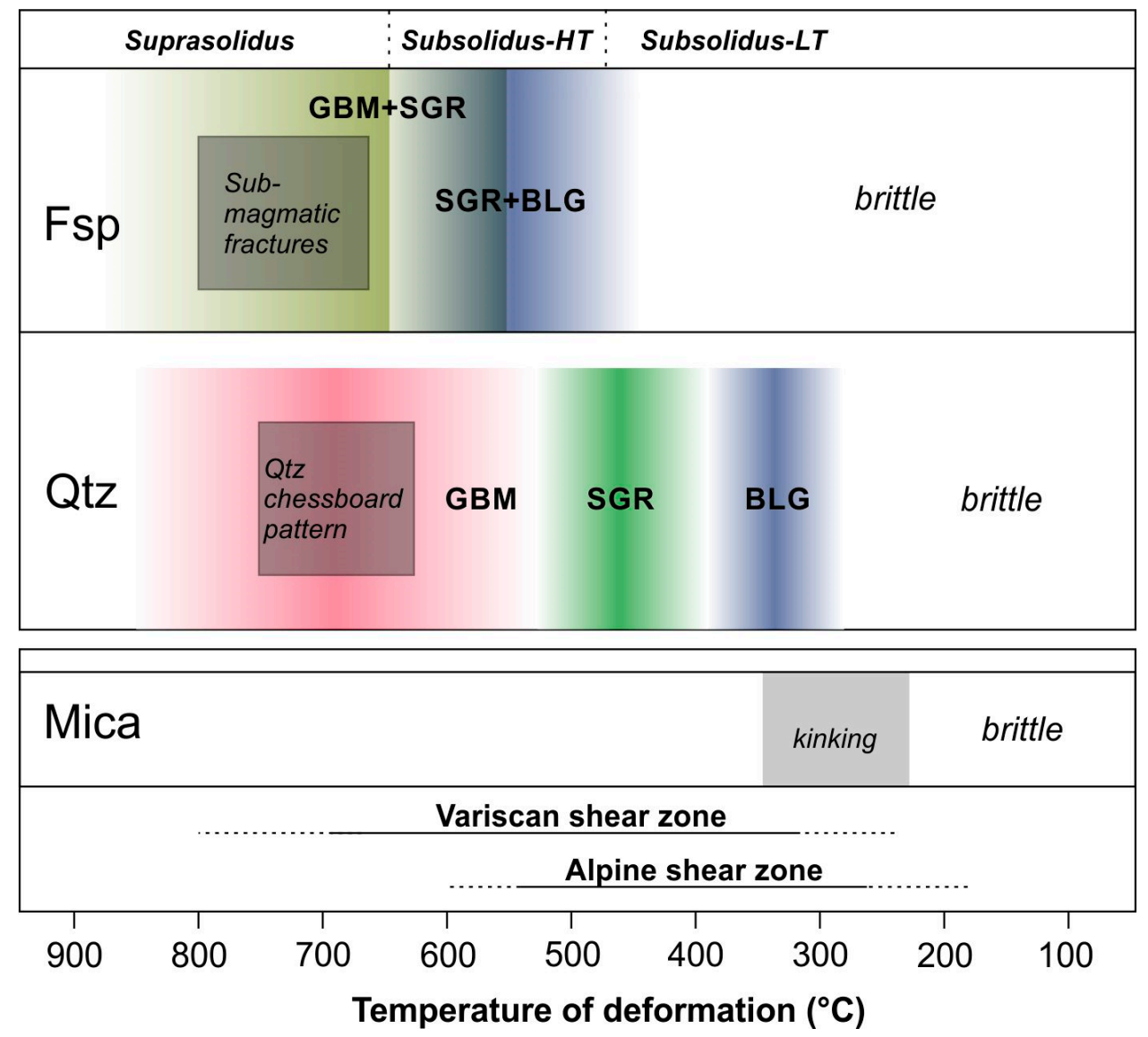

Figure 9. Submagmatic to solid state thermal ranges of deformation mechanisms and associated microstructures for various minerals (feldspar, quartz, and mica) recognized in the studied granitoid rocks (temperature range estimates after [95,96,98,138-141]. BLG = bulging recrystallization; SGR = subgrain rotation recrystallization; GBM = grain boundary migration recrystallization . Thermal conditions for Variscan syntectonic granitoids and Alpine shear zones in the Calabria-Peloritani Orogen are also shown (after [51] and references therein).

The similar distribution of deformation microstructures observed in both trondhjemites and low-Ca granitoids supports the proposal that temperature is the main factor controlling the activation of specific deformation mechanisms (e.g., $[98,129]$ ), compared to the confining pressure and rock grain size. The only exception might be the different occurrence of core-and-mantle structures in quartz that appears to be higher in the finer-grained low-Ca granitoids.

We observed also that the most frequent microstructure, in both granitoids, is the ribbon quartz, whereas the rarest is the quartz GBM recrystallization. This suggests that the dominant mechanism activated in the deformed cooling granitoids, and/or better preserved during subsequent deformation at lower temperatures, was HT subgrain rotation associated to a shear strain gradient (e.g., [142]). This explanation might account, in turn, for the coupled low incidence of the quartz GBM in both studied granitoids, by considering that both ribbon quartz and grain boundary migration can develop at similar temperatures, but at sensibly different strain conditions. A quite similar conclusion is that ribbon quartz may have reworked previously formed GBM related microstructures.

Finally, submagmatic fractures are also quite rare, but this is an expected result, due to the very transient near-solidus conditions at which these microstructures can develop. 


\subsection{Implications for Shear-Assisted Exhumation}

Microstructural evidences obtained for the granitoids of Forte Cavalli area in the north-eastern Peloritani Mountains, integrated by existing geochronological data, indicate long-lived late-Variscan shear zone activity coeval with granitoid magma emplacement and cooling for a period of $\sim 20 \mathrm{Ma}$. The earliest granitoid magmas were produced by water-fluxed melting of metagreywackes at pressure likely close to 1.0 GPa ([47]; and references therein), near the collision-related baric peak, giving rise to the trondhjemitic plutons that emplaced at $\sim 310 \mathrm{Ma}[49,50]$. According to the evidence obtained in this study, shearing started just after the emplacement of the magmatic trondhjemites, as documented by development of submagmatic fractures and chessboard patterns in quartz, and continued during cooling of the magmatic body, as shown by repeated superposition of subsolidus deformation microstructures of progressively lower temperature (Figures 7-9).

In the contiguous Pizzo Bottino pluton, the trondhjemites intrude metagreywacke metatexites with trondhjemite leucosomes that are considered to have been also produced by water-fluxed melting at PT conditions of $\sim 1.0 \mathrm{GPa}$ and $700{ }^{\circ} \mathrm{C}$, starting at around 340-330 Ma [65]. The migmatites were then slightly heated during decompression up to Ms-dehydration melting conditions, producing granitic leucosome melt and, finally, totally solidified before the emplacement of the trondhjemite pluton at $\sim 310 \mathrm{Ma}$ and $\sim 0.5 \mathrm{GPa}$ ([65] and references therein). The migmatite path, from early migmatization at $\sim 1.0 \mathrm{GPa}$ to final solidification at $\sim 0.5 \mathrm{GPa}$, implies a significant decompression with associated post-collisional crustal exhumation of $\sim 14 \mathrm{~km}$.

No evidence for shear zone involvement in this early exhumation stage has been found in the above mentioned migmatites, that appear to have recorded shear-related deformation at high temperature, but only after their complete solidification [65]. On the other hand, submagmatic fractures appear to be absent also in the migmatites from the Forte Cavalli area, but chessboard extinction in quartz is locally present, suggesting possible deformation in the presence of melt. In this respect, it is however to be considered that the rapid transition of the host rocks in the study area from unmigmatized paragneisses to metatexites approaching the granitoid complex, with rare diatexites in the inner part (Figure 2), suggests that migmatization might have been induced by magma emplacement in the upper amphibolite facies paragneisses.

After magma intrusion and extensive crystallization, the trondhjemite plutons were uplifted, together with their metamorphic host rocks, and were then intruded by the granite magmas at $\sim 300 \mathrm{Ma}$ [47-50] and at lower pressure of $\sim 0.3 \mathrm{GPa}$. In this case, the presence of shear-related microstructures developed in the trondhjemites from submagmatic to low temperature subsolidus conditions indicate that this second-stage exhumation, from a depth of about $14 \mathrm{~km}$ to a depth of about $8 \mathrm{~km}$ was assisted by shear zone activity.

Then, also the younger granites were in turn affected by shearing during cooling, starting to record deformation at sub-magmatic conditions, with diffuse formation of submagmatic fractures and chessboard patterns in quartz, followed by subsolidus deformation at progressively lower temperature.

The occurrence of domino-torn boudins in tiny andalusite crystals, in conjunction with stretched and pinch-and-swell garnet porphyroclasts in phyllites from the central Peloritani Mountains [46], suggests that late-Variscan exhumation involving the Peloritanian granites occurred under an extensional regime.

On the whole, considering that migmatites formed at $\sim 1.0 \mathrm{GPa}$ were intruded by granites at $\sim 0.3 \mathrm{GPa}$, implies that late-Variscan post-collisional evolution involved $\sim 20 \mathrm{~km}$ of exhumation of deep continental crust.

Shear-related deformation continued during cooling of the granites down to low-temperature conditions in a ductile and, finally, brittle regime. 


\section{Conclusions}

Investigation of the microstructures exhibited by late-Variscan trondhjemites ( 310 Ma) and granites ( 300 Ma) intruded in high-grade paragneisses from the Peloritani Mountains (southern Italy) revealed, for the first time, that both granitoids were affected by shear-related deformation from submagmatic $\left(\mathrm{T}>650{ }^{\circ} \mathrm{C}\right.$ ) to low temperature solid state conditions $\left(\mathrm{T}<300{ }^{\circ} \mathrm{C}\right)$. Non-coaxial deformation is documented by sigmoidal porphyroclasts, mica fish and domino-torn boudins developed in tiny andalusite crystals. The occurrence of chessboard patterns in quartz and, especially, of submagmatic fractures noticeably indicates deformation in the presence of melt and, therefore, reliably constrains the activity of the shear zone during the solidification of the granitoid magmas, at the final stages of the Variscan orogenic cycle. This result could support the proposed location of the Peloritani Variscan basement within a peripheral branch of the East Variscan Shear Zone [54,55].

Submagmatic deformation was extensively superseded by continuous subsolidus deformation at progressively lower temperatures. Examples of solid state-high temperature deformation microstructures $\left(\mathrm{T}>450{ }^{\circ} \mathrm{C}\right.$ ) include feldspar bulging and quartz grain boundary migration recrystallization, quartz ribbons and core-and-mantle structures. Finally, low temperature subsolidus microstructures consist of quartz subgrain rotation recrystallization, bulging, mica kinks, and feldspar twinning and bending. Each type of deformation microstructure is often placed side by side with others of lower or higher temperature, documenting the progressive change of the deformation mechanisms in the single minerals and mineral aggregates upon decreasing temperature. Comparison of the shear-related microstructures developed in the older trondhjemites, emplaced at higher depth $(\sim 0.5 \mathrm{GPa})$ and younger granites, emplaced at shallower crustal levels ( $\sim .3 \mathrm{GPa})$ reveals no systematic relationship between deformation mechanisms and emplacement depth, or rock grain size, during different evolutionary stages of the shear zone. The only exception might be the higher incidence of core and mantle structures of quartz grains in the low-Ca granitoids, possibly reflecting the higher amount of grain boundaries per volume unit in finer-grained rocks.

The two continuous sequences of submagmatic to low-temperature shear-related deformation, recorded in both the older and younger granitoids, suggest a duration of $\sim 20 \mathrm{Ma}$ for shear activity during syn-magmatic post-collisional exhumation of the Variscan middle crust in southernmost Italy.

Author Contributions: Conceptualization, E.F., P.F., and R.C.; methodology, E.F. and P.F.; investigation, E.F., P.F., and D.R.; resources, P.F.; writing-original draft preparation, E.F., P.F., and D.R.; supervision, E.F., P.F., and R.C. All authors have read and agreed to the published version of the manuscript.

Funding: This research received no external funding.

Acknowledgments: We thank three anonymous reviewers for their constructive comments and suggestions that helped us to greatly improve the manuscript. We would like also to thank the journal editors and guest editor C.M. for careful editorial handling.

Conflicts of Interest: The authors declare no conflict of interest.

\section{References}

1. Fazio, E.; Ortolano, G.; Visalli, R.; Alsop, I.; Cirrincione, R.; Pezzino, A. Strain localization and sheath fold development during progressive deformation in a ductile shear zone: A case study of macro-to micro-scale structures from the Aspromonte Massif, Calabria. Ital. J. Geosci. 2018, 137, 208-218. [CrossRef]

2. Pezzino, A.; Angi, G.; Fazio, E.; Fiannacca, P.; Lo Giudice, A.; Ortolano, G.; Punturo, R.; Cirrincione, R.; de Vuono, E. Alpine metamorphism in the aspromonte massif: Implications for a new framework for the southern sector of the Calabria-Peloritani Orogen, Italy. Int. Geol. Rev. 2008, 50, 423-441. [CrossRef]

3. Carosi, R.; Montomoli, C.; Rubatto, D.; Visonà, D. Late Oligocene high-temperature shear zones in the core of the Higher Himalayan Crystallines (Lower Dolpo, western Nepal). Tectonics 2010, 29. [CrossRef]

4. Carosi, R.; Montomoli, C.; Rubatto, D.; Visonà, D. Leucogranite intruding the South Tibetan Detachment in western Nepal: Implications for exhumation models in the Himalayas. Terra Nova 2013, 25, 478-489. [CrossRef] 
5. Montomoli, C.; Iaccarino, S.; Carosi, R.; Langone, A.; Visonà, D. Tectonometamorphic discontinuities within the Greater Himalayan Sequence in Western Nepal (Central Himalaya): Insights on the exhumation of crystalline rocks. Tectonophysics 2013, 608, 1349-1370. [CrossRef]

6. Brown, M.; Solar, G.S. Granite ascent and emplacement during contractional deformation in convergent orogens. J. Struct. Geol. 1998, 20, 1365-1393. [CrossRef]

7. Florisbal, L.M.; de Assis Janasi, V.; de Fátima Bitencourt, M.; Heaman, L.M. Space-time relation of post-collisional granitic magmatism in Santa Catarina, southern Brazil: U-Pb LA-MC-ICP-MS zircon geochronology of coeval mafic-felsic magmatism related to the Major Gercino Shear Zone. Precambrian Res. 2012, 216-219, 132-151. [CrossRef]

8. Florisbal, L.M.; de Bitencourt, M.F.; de Janasi, V.A.; Nardi, L.V.S.; Heaman, L.M. Petrogenesis of syntectonic granites emplaced at the transition from thrusting to transcurrent tectonics in post-collisional setting: Whole-rock and $\mathrm{Sr}-\mathrm{Nd}-\mathrm{Pb}$ isotope geochemistry in the Neoproterozoic Quatro Ilhas and Mariscal Granites, Southern Brazil. Seventh Hutton Symp. Granites Relat. Rocks 2012, 153, 53-71. [CrossRef]

9. Vigneresse, J.L. Control of granite emplacement by regional deformation. Tectonophysics 1995, 249, $173-186$. [CrossRef]

10. Weinberg, R.F.; Sial, A.N.; Mariano, G. Close spatial relationship between plutons and shear zones. Geology 2004, 32, 377-380. [CrossRef]

11. Weinberg, R.F.; Mark, G.; Reichardt, H. Magma ponding in the Karakoram shear zone, Ladakh, NW India. GSA Bull. 2009, 121, 278-285. [CrossRef]

12. Bouchez, J.-L.; Hutton, D.; Stephens, E.W. Granite: From Segregation of Melt to Emplacement Fabrics; Springer Science \& Business Media: Berlin/Heidelberg, Germany, 2013; Volume 8.

13. Punturo, R.; Cirrincione, R.; Fazio, E.; Fiannacca, P.; Kern, H.; Mengel, K.; Ortolano, G.; Pezzino, A. Microstructural, compositional and petrophysical properties of mylonitic granodiorites from an extensional shear zone (Rhodope Core complex, Greece). Geol. Mag. 2014, 151, 1051-1071. [CrossRef]

14. Punturo, R.; Cirrincione, R.; Fazio, E.; Fiannacca, P.; Kern, H.; Mengel, K.; Ortolano, G.; Pezzino, A. Quartz deformation mechanisms in shear zones inferred by quantitative microstructural investigation: The case study of Kavala (Rhodope Massif, north-eastern Greece). Rend. Online Soc. Geol. Ital. 2012, 21, $146-147$.

15. Fiannacca, P.; Williams, I.S.; Cirrincione, R. Timescales and mechanisms of batholith construction: Constraints from zircon oxygen isotopes and geochronology of the late Variscan Serre Batholith (Calabria, Southern Italy). Lithos 2017, 277, 302-314. [CrossRef]

16. Burov, E.; Jolivet, L.; Le Pourhiet, L.; Poliakov, A. A thermomechanical model of exhumation of high pressure (HP) and ultra-high pressure (UHP) metamorphic rocks in Alpine-type collision belts. Tectonophysics 2001, 342, 113-136. [CrossRef]

17. Schulmann, K.; Kröner, A.; Hegner, E.; Wendt, I.; Konopásek, J.; Lexa, O.; Štípská, P. Chronological constraints on the pre-orogenic history, burial and exhumation of deep-seated rocks along the eastern margin of the Variscan orogen, Bohemian Massif, Czech Republic. Am. J. Sci. 2005, 305, 407-448. [CrossRef]

18. Siebenaller, L.; Vanderhaeghe, O.; Jessell, M.; Boiron, M.-C.; Hibsch, C. Syntectonic fluids redistribution and circulation coupled to quartz recrystallization in the ductile crust (Naxos Island, Cyclades, Greece). J. Geodyn. 2016, 101, 129-141. [CrossRef]

19. Gloaguen, E.; Branquet, Y.; Chauvet, A.; Bouchot, V.; Barbanson, L.; Vigneresse, J.-L. Tracing the magmatic/hydrothermal transition in regional low-strain zones: The role of magma dynamics in strain localization at pluton roof, implications for intrusion-related gold deposits. J. Struct. Geol. 2014, 58, 108-121. [CrossRef]

20. Dipple, G.M.; Ferry, J.M. Metasomatism and fluid flow in ductile fault zones. Contrib. Miner. Pet. 1992, 112, 149-164. [CrossRef]

21. Bierlein, F.P.; Groves, D.I.; Goldfarb, R.J.; Dubé, B. Lithospheric controls on the formation of provinces hosting giant orogenic gold deposits. Min. Depos. 2006, 40, 874. [CrossRef]

22. Harlov, D.E.; Austrheim, H. Metasomatism and the Chemical Transformation of Rock: Rock-Mineral-Fluid Interaction in Terrestrial and Extraterrestrial Environments. In Metasomatism and the Chemical Transformation of Rock: The Role of Fluids in Terrestrial and Extraterrestrial Processes; Harlov, D.E., Austrheim, H., Eds.; Springer: Berlin/Heidelberg, Germany, 2013; pp. 1-16, ISBN 978-3-642-28394-9. 
23. Klepeis, K.A.; Daczko, N.R.; Clarke, G.L. Kinematic vorticity and tectonic significance of superposed mylonites in a major lower crustal shear zone, northern Fiordland, New Zealand. J. Struct. Geol. 1999, 21, 1385-1405. [CrossRef]

24. Fazio, E.; Punturo, R.; Cirrincione, R.; Ortolano, G.; Pezzino, A. Quantitative microstructures of polycrystalline quartz aggregates in a mylonite: Implication for strain-rate evaluation. Rend. Online Soc. Geol. Ital. 2013, 29, 47-50.

25. Ortolano, G.; Visalli, R.; Fazio, E.; Fiannacca, P.; Godard, G.; Pezzino, A.; Punturo, R.; Sacco, V.; Cirrincione, R. Tectono-metamorphic evolution of the Calabria continental lower crust: The case of the Sila Piccola Massif. Int. J. Earth Sci. 2020, 109, 1295-1319. [CrossRef]

26. Cirrincione, R.; Fazio, E.; Ortolano, G.; Pezzino, A.; Punturo, R. Fault-related rocks: Deciphering the structural-metamorphic evolution of an accretionary wedge in a collisional belt, NE Sicily. Int. Geol. Rev. 2012, 54, 940-956. [CrossRef]

27. Ortolano, G.; Fazio, E.; Visalli, R.; Alsop, G.I.; Pagano, M.; Cirrincione, R. Quantitative microstructural analysis of mylonites formed during Alpine tectonics in the western Mediterranean realm. J. Struct. Geol. 2020. [CrossRef]

28. Fazio, E.; Cirrincione, R.; Pezzino, A. Estimating P-T conditions of alpine-type metamorphism using multistage garnet in the tectonic windows of the Cardeto area (southern Aspromonte Massif, Calabria). Miner. Pet. 2008, 93, 111-142. [CrossRef]

29. Vignaroli, G.; Rossetti, F.; Theye, T.; Faccenna, C. Styles and regimes of orogenic thickening in the Peloritani Mountains (Sicily, Italy): New constraints on the tectono-metamorphic evolution of the Apennine belt. Geol. Mag. 2008, 145, 552-569. [CrossRef]

30. Cirrincione, R.; Fazio, E.; Fiannacca, P.; Ortolano, G.; Punturo, R. Microstructural investigation of naturally deformed leucogneiss from an alpine shear zone (Southern Calabria-Italy). Pure Appl. Geophys. 2009, 166, 995-1010. [CrossRef]

31. Fazio, E.; Cirrincione, R.; Pezzino, A. Garnet crystal growth in sheared metapelites (southern Calabria-Italy): Relationships between isolated porphyroblasts and coalescing euhedral crystals. Period. Miner. 2009, 78, 3-18. [CrossRef]

32. Cirrincione, R.; De Vuono, E.; Fazio, E.; Fiannacca, P.; Ortolano, G.; Pezzino, A.; Punturo, R. The composite framework of the southern sector of the Calabria Peloritani Orogen. Rend. Online Soc. Geol. Ital. 2010, 11, $93-94$.

33. Fazio, E.; Punturo, R.; Cirrincione, R. Quartz c-axis texture mapping of mylonitic metapelite with rod structures (Calabria, southern Italy): Clues for hidden shear flow direction. J. Geol. Soc. India 2010, 75, 171-182. [CrossRef]

34. Fazio, E.; Cirrincione, R.; Pezzino, A. Tectono-metamorphic map of the south-western flank of the Aspromonte Massif (southern Calabria -Italy). J. Maps 2015, 11, 85-100. [CrossRef]

35. Fazio, E.; Punturo, R.; Cirrincione, R.; Kern, H.; Pezzino, A.; Wenk, H.-R.; Goswami, S.; Mamtani, M.A. Quartz preferred orientation in naturally deformed mylonitic rocks (Montalto shear zone-Italy): A comparison of results by different techniques, their advantages and limitations. Int. J. Earth Sci. 2017, 106, 2259-2278. [CrossRef]

36. Rottura, A.; Bargossi, G.M.; Caironi, V.; Del Moro, A.; Maccarrone, E.; Macera, P.; Paglionico, A.; Petrini, R.; Piccarreta, G.; Poli, G. Petrogenesis of contrasting Hercynian granitoids from the Calabrian Arc, southern Italy. Lithos 1990. [CrossRef]

37. Caggianelli, A.; Prosser, G.; Di Battista, P. Textural features and fabric analysis of granitoids emplaced at different depths: The example of the Hercynian tonalites and granodiorites from Calabria. Miner. Petrogr. Acta 1997, 40, 11-26.

38. Caggianelli, A.; Prosser, G.; Del Moro, A. Cooling and exhumation history of deep-seated and shallow level, late Hercynian granitoids from Calabria. Geol. J. 2000, 35, 33-42. [CrossRef]

39. Festa, V. C-axis fabrics of quartz-ribbons during high-temperature deformation of syn-tectonic granitoids (Sila Massif, Calabria, Italy). C. R. Geosci. 2009, 341, 557-567. [CrossRef]

40. Festa, V.; Caggianelli, A.; Kruhl, J.H.; Liotta, D.; Prosser, G.; Gueguen, E.; Paglionico, A. Late-Hercynian shearing during crystallization of granitoid magmas (Sila massif, southern Italy): Regional implications. Geodin. Acta 2006, 19, 185-195. [CrossRef]

41. Festa, V.; Tursi, F.; Caggianelli, A.; Spiess, R. The tectono-magmatic setting of the Hercynian upper continental crust exposed in Calabria (Italy) as revealed by the 1:10,000 structural-geological map of the Levadio stream area. Ital. J. Geosci. 2018, 137, 165-174. [CrossRef] 
42. Festa, V.; Fornelli, A.; Paglionico, A.; Pascazio, A.; Piccarreta, G.; Spiess, R. Asynchronous extension of the late-Hercynian crust in Calabria. Tectonophysics 2012, 518, 29-43. [CrossRef]

43. Liotta, D.; Festa, V.; Caggianelli, A.; Prosser, G.; Pascazio, A. Mid-crustal shear zone evolution in a syn-tectonic late Hercynian granitoid (Sila Massif, Calabria, southern Italy). Int. J. Earth Sci. 2004, 93, 400-413. [CrossRef]

44. Liotta, D.; Caggianelli, A.; Kruhl, J.H.; Festa, V.; Prosser, G.; Langone, A. Multiple injections of magmas along a Hercynian mid-crustal shear zone (Sila Massif, Calabria, Italy). J. Struct. Geol. 2008, 30, 1202-1217. [CrossRef]

45. De Gregorio, S.; Rotolo, S.G.; Villa, I.M. Geochronology of the medium to high-grade metamorphic units of the Peloritani Mts., Sicily. Int. J. Earth Sci. 2003, 92, 852-872. [CrossRef]

46. Fiannacca, P.; Lo Pò, D.; Ortolano, G.; Cirrincione, R.; Pezzino, A. Thermodynamic modeling assisted by multivariate statistical image analysis as a tool for unraveling metamorphic P-T-d evolution: An example from ilmenite-garnet-bearing metapelite of the Peloritani Mountains, Southern Italy. Miner. Pet. 2012, 106, 151-171. [CrossRef]

47. Fiannacca, P.; Basei, M.A.S.; Cirrincione, R.; Pezzino, A.; Russo, D. Water-assisted production of late-orogenic trondhjemites at magmatic and subsolidus conditions. Geol. Soc. Lond. Spec. Publ. 2020, 491, 147-178. [CrossRef]

48. Graessner, T.; Schenk, V.; Bröcker, M.; Mezger, K. Geochronological constraints on the timing of granitoid magmatism, metamorphism and post-metamorphic cooling in the Hercynian crustal cross-section of Calabria. J. Metamorph. Geol. 2000, 18, 409-421. [CrossRef]

49. Fiannacca, P.; Williams, I.S.; Cirrincione, R.; Pezzino, A. Crustal contributions to late hercynian peraluminous magmatism in the Southern Calabria-Peloritani Orogen, Southern Italy: Petrogenetic inferences and the gondwana connection. J. Pet. 2008, 49, 1497-1514. [CrossRef]

50. Stella, M.L.P. Petrogenesi e Geocronologia U-Th-Pb Di Rocce Granitoidi Affioranti Nel Settore Nord-Orientale Dei Monti Peloritani (Sicilia Nord-Orientale). PhD. Thesis, Catania University, Catania, Italy, 2010.

51. Cirrincione, R.; Fazio, E.; Fiannacca, P.; Ortolano, G.; Pezzino, A.; Punturo, R. The Calabria-Peloritani Orogen, a composite terrane in Central Mediterranean; Its overall architecture and geodynamic significance for a pre-Alpine scenario around the Tethyan basin. Period. Miner. 2015, 84, 701-749. [CrossRef]

52. Carosi, R.; Montomoli, C.; Tiepolo, M.; Frassi, C. Geochronological constraints on post-collisional shear zones in the Variscides of Sardinia (Italy). Terra Nova 2012, 24, 42-51. [CrossRef]

53. Corsini, M.; Rolland, Y. Late evolution of the southern European Variscan belt: Exhumation of the lower crust in a context of oblique convergence. Comptes Rendus Geosci. 2009, 341, 214-223. [CrossRef]

54. Padovano, M.; Elter, F.M.; Pandeli, E.; Franceschelli, M. The East Variscan Shear Zone: New insights into its role in the Late Carboniferous collision in southern Europe. Int. Geol. Rev. 2012, 54, 957-970. [CrossRef]

55. Padovano, M.; Dörr, W.; Elter, F.M.; Gerdes, A. The East Variscan Shear Zone: Geochronological constraints from the Capo Ferro area (NE Sardinia, Italy). Lithos 2014, 196-197, 27-41. [CrossRef]

56. Acquafredda, P.; Lorenzoni, S.; Lorenzoni, E.Z. Palaeozoic sequences and evolution of the Calabrian-Peloritan Arc (Southern Italy). Terra Nova 1994, 6, 582-594. [CrossRef]

57. Cirrincione, R.; Fiannacca, P.; Giudice, A.L.; Pezzino, A. Evidence of early Palaeozoic continental rifting from mafic metavolcanics of Southern Peloritani Mountains (north-eastern Sicily, Italy). Ofioliti 2005, 30, $15-25$.

58. Somma, R.; Navas-Parejo, P.; Martín-Algarra, A.; Rodríguez-Cañero, R.; Perrone, V.; Martínez-Pérez, C. Paleozoic stratigraphy of the Longi-Taormina Unit (PeloritanianMountains, southern Italy). Stratigraphy 2013, 10, 127-152.

59. Ferla, P.; Meli, C. Petrogenesis of tourmaline rocks associated with Fe-carbonate-graphite metapelite, metabasite and strata-bound polymetallic sulphide mineralisation, Peloritani Mountains, Sicily, Southern Italy. Lithos 2007, 99, 266-288. [CrossRef]

60. Atzori, P.; Ferla, P.; Paglionico, A.; Piccarreta, G.; Rottura, A. Remnants of the Hercynian orogen along the "Calabrian-Peloritan arc", southern Italy: A review. J. Geol. Soc. 1984, 141, 137. [CrossRef]

61. Rottura, A.; Caggianelli, A.; Campana, R.; Del Moro, A. Petrogenesis of Hercynian peraluminous granites from the Calabrian Arc, Italy. Eur. J. Miner. 1993, 5, 737-754. [CrossRef]

62. Ferla, P. A model of continental crust evolution in the geological history of the Peloritani Mountains (Sicily). Mem. Soc. Geol. Ital. 2000, 55, 87-93. 
63. Fiannacca, P.; Brotzu, P.; Cirrincione, R.; Mazzoleni, P.; Pezzino, A. Alkali metasomatism as a process for trondhjemite genesis: Evidence from Aspromonte Unit, north-eastern Peloritani, Sicily. Miner. Pet. 2005, 84, 19-45. [CrossRef]

64. Fiannacca, P.; Williams, I.S.; Cirrincione, R.; Pezzino, A. Poly-orogenic melting of metasedimentary crust from a granite geochemistry and inherited zircon perspective (southern calabria-peloritani orogen, Italy). Front. Earth Sci. 2019, 7, 199. [CrossRef]

65. Fiannacca, P.; Cirrincione, R. Metasedimentary metatexites with trondhjemitic leucosomes from NE sicily: Another example of prograde water-fluxed melting in collisional belts. Geosci. Switz. 2020, 10, 123. [CrossRef]

66. Williams, I.S.; Fiannacca, P.; Cirrincione, R.; Pezzino, A. Peri-Gondwanan origin and early geodynamic history of NE Sicily: A zircon tale from the basement of the Peloritani Mountains. Gondwana Res. 2012, 22, 855-865. [CrossRef]

67. Atzori, P.; Cirrincione, R.; Del Moro, A.; Pezzino, A. Structural, metamorphic and geochronologic features of the Alpine event in the south-eastern sector of the Peloritani Mountains (Sicily). Period. Miner. 1994, 63, 113-125.

68. Bonardi, G.; Compagnoni, R.; Aldo Moro, D.E.L.; Macaione, E.; Messina, A.; Perrone, V. Rb-Sr age constraints on the alpine metamorphic overprint in the aspromonte nappe (Calabria-Peloritani composite terrane, southern Italy). Ital. J. Geosci. 2008, 127, 173-190.

69. Ioppolo, S.; Puglisi, G. Studio petrologico di alcune metamorfiti erciniche dei Monti Peloritani nord orientali (Sicilia). Rend. Della Soc. Ital. Miner. E Pet. 1989, 43, 643-656.

70. Ortolano, G.; Cirrincione, R.; Pezzino, A. P-T evolution of Alpine metamorphism in the southern Aspromonte Massif (Calabria - Italy). Schweiz. Miner. Petrogr. Mitt. 2005, 85, 31-56.

71. Ortolano, G.; Cirrincione, R.; Pezzino, A.; Tripodi, V.; Zappala, L. Petro-structural geology of the Eastern Aspromonte Massif crystalline basement (southern Italy-Calabria): An example of interoperable geo-data management from thin section-To field scale. J. Maps 2015, 11, 181-200. [CrossRef]

72. Ortolano, G.; Visalli, R.; Cirrincione, R.; Rebay, G. PT-path reconstruction via unraveling of peculiar zoning pattern in atoll shaped garnets via image assisted analysis: An example from the Santa Lucia del Mela garnet micaschists (Northeastern Sicily-Italy). Period. Miner. 2014, 83, 257-297. [CrossRef]

73. von Raumer, J.F.; Stampfli, G.M. The birth of the Rheic Ocean-Early Palaeozoic subsidence patterns and subsequent tectonic plate scenarios. Tectonophysics 2008, 461, 9-20. [CrossRef]

74. von Raumer, J.F.; Bussy, F.; Schaltegger, U.; Schulz, B.; Stampfli, G.M. Pre-Mesozoic Alpine basements-Their place in the European Paleozoic framework. GSA Bull. 2013, 125, 89-108. [CrossRef]

75. Domeier, M.; Torsvik, T.H. Plate tectonics in the late Paleozoic. Geosci. Front. 2014, 5, 303-350. [CrossRef]

76. Fiannacca, P.; Cirrincione, R.; Bonanno, F.; Carciotto, M.M. Source-inherited compositional diversity in granite batholiths: The geochemical message of Late Paleozoic intrusive magmatism in central Calabria (southern Italy). Lithos 2015, 236, 123-140. [CrossRef]

77. Ayuso, R.A.; Messina, A.; De Vivo, B.; Russo, S.; Woodruff, L.G.; Sutter, J.F.; Belkin, H.E. Geochemistry and argon thermochronology of the Variscan Sila Batholith, southern Italy: Source rocks and magma evolution. Contrib. Miner. Pet. 1994, 117, 87-109. [CrossRef]

78. Punturo, R.; Mamtani, M.A.; Fazio, E.; Occhipinti, R.; Renjith, A.R.; Cirrincione, R. Seismic and magnetic susceptibility anisotropy of middle-lower continental crust: Insights for their potential relationship from a study of intrusive rocks from the Serre Massif (Calabria, southern Italy). Tectonophysics 2017, 712-713, 542-556. [CrossRef]

79. D'Amico, C.; Rottura, A.; Maccarrone, E.; Puglisi, G. Peraluminous granitic suite of Calabria- Peloritani arc (southern Italy). Rend. Soc. Ital. Miner. E Pet. 1982, 38, 35-52.

80. Festa, V.; Langone, A.; Caggianelli, A.; Rottura, A. Dike magmatism in the Sila Grande (Calabria, southern Italy): Evidence of Pennsylvanian-Early Permian exhumation. Geosphere 2010, 6, 549-566. [CrossRef]

81. Romano, V.; Cirrincione, R.; Fiannacca, P.; Lustrino, M.; Tranchina, A. Late-Hercynian post-collisional dyke magmatism in central Calabria (Serre Massif, southern Italy). Period. Miner. 2011, 80, 489-515. [CrossRef]

82. Romano, V.; Cirrincione, R.; Fiannacca, P.; Tranchina, A.; Villa, I.M. Petrologic constraints on post-Variscan andesite dyke magmatism in the Sila Massif (northern Calabria). Rend. Online Soc. Geol. Ital. 2012, 21, $148-150$.

83. Barca, D.; Cirrincione, R.; De Vuono, E.; Fiannacca, P.; Ietto, F.; Lo Guidice, A. The Triassic rift system in the northern Calabrian-Peloritani Orogen: Evidence from basaltic dyke magmatism in the san donato unit. Period. Miner. 2010, 79, 61-72. [CrossRef] 
84. Cirrincione, R.; Fiannacca, P.; Lustrino, M.; Romano, V.; Tranchina, A. Late Triassic tholeiitic magmatism in Western Sicily: A possible extension of the Central Atlantic Magmatic Province (CAMP) in the Central Mediterranean area $\alpha$. Lithos 2014, 188, 60-71. [CrossRef]

85. Cirrincione, R.; Fiannacca, P.; Lustrino, M.; Romano, V.; Tranchina, A.; Villa, I.M. Enriched asthenosphere melting beneath the nascent North African margin: Trace element and Nd isotope evidence in middle-late Triassic alkali basalts from central Sicily (Italy). Int. J. Earth Sci. 2016, 105, 595-609. [CrossRef]

86. Atzori, P.; Vezzani, L. Lineamenti petrografico-strutturali della catena peloritana. Geol. Romana 1974, 13, 21-27.

87. Lo Giudice, A.; Atzori, P.; Pezzino, A. Genesi delle masse chiare peloritane ed implicazioni sulle rocce paragneissiche. Miner. Petrogr. Acta Bologna 1985, 29, 93-117.

88. Macaione, E.; Messina, A.; Bonanno, R.; Carabetta, M.T. An Itinerary through Proterozoic to holocene rocks in the north-Eastern Peloritani Mts. (southern Italy). Geol. Field Trips Maps 2010, 2, 1-98. [CrossRef]

89. Atzori, P.; Del Moro, A.; Rottura, A. Rb/Sr radiometric data from medium- to high-grade metamorphic rocks (Aspromonte nappe) of the north-eastern Peloritani Mountains (Calabrian Arc), Italy. Eur. J. Miner. 1990, 2 , 363-371. [CrossRef]

90. Appel, P.; Cirrincione, R.; Fiannacca, P.; Pezzino, A. Age constraints on Late Paleozoic evolution of continental crust from electron microprobe dating of monazite in the Peloritani Mountains (southern Italy): Another example of resetting of monazite ages in high-grade rocks. Int. J. Earth Sci. 2010, 100, 107-123. [CrossRef]

91. Bouchez, J.L.; Delas, C.; Gleizes, G.; Nedelec, A.; Cuney, M. Submagmatic microfractures in granites. Geology 1992, 20, 35-38. [CrossRef]

92. Buttner, H.L. The geometric evolution of structures in granite during continous deformation from magmatic to solid-state conditions: An example from the central European Variscan Belt. Am. Miner. 1999, 84, 1781-1792. [CrossRef]

93. Blenkinsop, T.G. Deformation Microstructures and Mechanisms in Minerals and Rocks; Springer Science \& Business Media: Berlin/Heidelberg, Germany, 2007.

94. Kruhl,J.H. Prism- and basal-plane parallel subgrain boundaries in quartz: A microstructural geothermobarometer. J. Metamorph. Geol. 1996, 14, 581-589. [CrossRef]

95. Guillope, M.; Poirier, J.P. Dynamic recrystallization during creep of single-crystalline halite: An experimental study. J. Geophys. Res. 1979, 84, 5557-5567. [CrossRef]

96. Urai, J.L.; Means, W.D.; Lister, G.S. Dynamic Recrystallization of Minerals; John Wiley \& Sons, Inc.: Hoboken, NJ, USA, 2011.

97. Parsons, A.J.; Phillips, R.J.; Lloyd, G.E.; Law, R.D.; Searle, M.P.; Walshaw, R.D. Mid-crustal deformation of the Annapurna-Dhaulagiri Himalaya, central Nepal: An atypical example of channel flow during the Himalayan orogeny. Geosphere 2016, 12, 985-1015. [CrossRef]

98. Passchier, C.W.; Trouw, R.A.J. Microtectonics; Springer: Berlin/Heidelberg, Germany, 2005; ISBN 3-540-64003-7.

99. Stipp, M.; Stünitz, H.; Heilbronner, R.; Schmid, S.M. The eastern Tonale fault zone: A "natural laboratory" for crystal plastic deformation of quartz over a temperature range from 250 to $700{ }^{\circ} \mathrm{C}$. J. Struct. Geol. 2002, 24, 1861-1884. [CrossRef]

100. Pawley, M.J.; Collins, W.J. The development of contrasting structures during the cooling and crystallisation of a syn-kinematic pluton. J. Struct. Geol. 2002, 24, 469-483. [CrossRef]

101. Lloyd, G.E.; Freeman, B. Dynamic recrystallization of quartz under greenschist conditions. J. Struct. Geol. 1994, 16, 867-881. [CrossRef]

102. Žák, J.; Verner, K.; Holub, F.V.; Kabele, P.; Chlupáčová, M.; Halodová, P. Magmatic to solid state fabrics in syntectonic granitoids recording early Carboniferous orogenic collapse in the Bohemian Massif. J. Struct. Geol. 2012, 36, 27-42. [CrossRef]

103. Zibra, I.; Kruhl, J.H.; Montanini, A.; Tribuzio, R. Shearing of magma along a high-grade shear zone: Evolution of microstructures during the transition from magmatic to solid-state flow. J. Struct. Geol. 2012, 37, 150-160. [CrossRef]

104. Gapais, D.; Barbarin, B. Quartz fabric transition in a cooling syntectonic granite (Hermitage Massif, France). Tectonophysics 1986, 125, 357-370. [CrossRef]

105. Zibra, I.; Kruhl, J.H.; Braga, R. Late Palaeozoic deformation of post-Variscan lower crust: Shear zone widening due to strain localization during retrograde shearing. Int. J. Earth Sci. 2010, 99, 973-991. [CrossRef] 
106. Menegon, L.; Nasipuri, P.; Stünitz, H.; Behrens, H.; Ravna, E. Dry and strong quartz during deformation of the lower crust in the presence of melt. J. Geophys. Res. Solid Earth 2011, 116, 1-23. [CrossRef]

107. Law, R.D. Deformation thermometry based on quartz c-axis fabrics and recrystallization microstructures: A review. J. Struct. Geol. 2014, 66, 129-161. [CrossRef]

108. Paterson, S.R.; Fowler, T.K.; Schmidt, K.L.; Yoshinobu, A.S.; Yuan, E.S.; Miller, R.B. Interpreting magmatic fabric patterns in plutons. Lithos 1998, 44, 53-82. [CrossRef]

109. Paterson, S.R.; Ardill, K.; Vernon, R.; Žák, J. A review of mesoscopic magmatic structures and their potential for evaluating the hypersolidus evolution of intrusive complexes. Back Future 2019, 125, 134-147. [CrossRef]

110. Mamtani, M.A.; Greiling, R.O. Serrated quartz grain boundaries, temperature and strain rate: Testing fractal techniques in a syntectonic granite. Geol. Soc. Lond. Spec. Publ. 2010, 332, 35. [CrossRef]

111. Angì, G.; Cirrincione, R.; Fazio, E.; Fiannacca, P.; Ortolano, G.; Pezzino, A. Metamorphic evolution of preserved Hercynian crustal section in the Serre Massif (Calabria-Peloritani Orogen, southern Italy). Lithos 2010, 115, 237-262. [CrossRef]

112. Caggianelli, A.; Liotta, D.; Prosser, G.; Ranalli, G. Pressure-temperature evolution of the late Hercynian Calabria continental crust: Compatibility with post-collisional extensional tectonics. Terra Nova 2007, 19, 502-514. [CrossRef]

113. Pereira, M.F.; Silva, J.B.; Drost, K.; Chichorro, M.; Apraiz, A. Relative timing of transcurrent displacements in northern Gondwana: U-Pb laser ablation ICP-MS zircon and monazite geochronology of gneisses and sheared granites from the western Iberian Massif (Portugal). Rheic Ocean. Palaeoz. Evol. Gondwana Laurussia Pangaea 2010, 17, 461-481. [CrossRef]

114. Gretter, N.; Ronchi, A.; Lopez-Gòmez, J.L.; Arche, A.; De la Horra, R.; Barrenechea, J.; Lago, M. The Late Paleozoic-Early Mesozoic from the Catalan Pyrenees (Spain): 60 Myr of environmental evolution in the frame of the western peri-Tethyan paleogeography. Earth Sci. Rev. 2015, 150, 679-708. [CrossRef]

115. Tartèse, R.; Boulvais, P.; Poujol, M.; Chevalier, T.; Paquette, J.-L.; Ireland, T.R.; Deloule, E. Mylonites of the South Armorican Shear Zone: Insights for crustal-scale fluid flow and water-rock interaction processes. Geodyn. Orogenesis 2012, 56-57, 86-107. [CrossRef]

116. Scheck, M.; Bayer, U.; Otto, V.; Lamarche, J.; Banka, D.; Pharaoh, T. The Elbe Fault System in North Central Europe-A basement controlled zone of crustal weakness. Tectonophysics 2002, 360, 281-299. [CrossRef]

117. Bouaziz, S.; Barrier, E.; Soussi, M.; Turki, M.M.; Zouari, H. Tectonic evolution of the northern African margin in Tunisia from paleostress data and sedimentary record. Tectonophysics 2002, 357, 227-253. [CrossRef]

118. Stampfli, G.M.; Borel, G.D. A plate tectonic model for the Paleozoic and Mesozoic constrained by dynamic plate boundaries and restored synthetic oceanic isochrons. Earth Planet. Sci. Lett. 2002, 196, 17-33. [CrossRef]

119. Stamfli, G.M.; Kozur, H.W. Europe from the Variscan to the Alpine cycles. Geol. Soc. Lond. Mem. 2006, 32, 57. [CrossRef]

120. von Raumer, J.F.; Bussy, F.; Stampfli, G.M. The Variscan evolution in the External massifs of the Alps and place in their Variscan framework. Mécanique Orogénie Varisque Une Vis. Mod. Rech. Dans Domaine Orogénie 2009, 341, 239-252. [CrossRef]

121. Elter, F.M.; Padovano, M. Discussion of "Deformation during exhumation of medium- and high-grade metamorphic rocks in the Variscan Chain in Northern Sardinia (Italy)" by Carosi R., Frassi C., Montomoli C., (2009). Geol. J. 2010, 45, 481-482. [CrossRef]

122. Simonetti, M.; Carosi, R.; Montomoli, C.; Corsini, M.; Petroccia, A.; Cottle, J.M.; Iaccarino, S. Timing and kinematics of flow in a transpressive dextral shear zone, Maures Massif (Southern France). Int. J. Earth Sci. 2020. [CrossRef]

123. Simonetti, M.; Carosi, R.; Montomoli, C.; Cottle, J.M.; Law, R.D. Transpressive Deformation in the Southern European Variscan Belt: New Insights From the Aiguilles Rouges Massif (Western Alps). Tectonics 2020, 39, e2020TC006153. [CrossRef]

124. Catalano, S.; Cirrincione, R.; Mazzoleni, P.; Pavano, F.; Pezzino, A.; Romagnoli, G.; Tortorici, G. The effects of a Meso-Alpine collision event on the tectono-metamorphic evolution of the Peloritani mountain belt (eastern Sicily, southern Italy). Geol. Mag. 2018, 155, 422-437. [CrossRef]

125. Micheletti, F.; Fornelli, A.; Piccarreta, G.; Barbey, P.; Tiepolo, M. The basement of Calabria (southern Italy) within the context of the Southern European Variscides: LA-ICPMS and SIMS U-Pb zircon study. Lithos 2008, 104, 1-11. [CrossRef] 
126. Fiannacca, P.; Williams, I.S.; Cirrincione, R.; Pezzino, A. The augen gneisses of the Peloritani Mountains (NE Sicily): Granitoid magma production during rapid evolution of the northern Gondwana margin at the end of the Precambrian. Gondwana Res. 2013, 23, 782-796. [CrossRef]

127. Langone, A.; Caggianelli, A.; Festa, V.; Prosser, G. Time Constraints on the Building of the Serre Batholith: Consequences for the Thermal Evolution of the Hercynian Continental Crust Exposed in Calabria (Southern Italy). J. Geol. 2014, 122, 183-199. [CrossRef]

128. Del Moro, A.; Pardini, G.; Maccarrone, E.; Rottura, A. Studio radiometrico Rb-Sr di granitoidi peraluminosi dell'arco calabro-peloritano. Rend. Soc. Ital. Miner. E Pet. 1982, 38, 1015-1026.

129. Cavalcante, C.; Lagoeiro, L.; Fossen, H.; Egydio-Silva, M.; Morales, L.F.G.; Ferreira, F.; Conte, T. Temperature constraints on microfabric patterns in quartzofeldsphatic mylonites, Ribeira belt (SE Brazil). J. Struct. Geol. 2018, 115, 243-262. [CrossRef]

130. Burov, E.; Jaupart, C.; Guillou-Frottier, L. Ascent and emplacement of buoyant magma bodies in brittle-ductile upper crust. J. Geophys. Res. Solid Earth 2003, 108. [CrossRef]

131. Burov, E.B. Rheology and strength of the lithosphere. Mar. Pet. Geol. 2011, 28, 1402-1443. [CrossRef]

132. Morgan, G.B.; London, D. Process of granophyre crystallization in the Long Mountain Granite, southern Oklahoma. GSA Bull. 2012, 124, 1251-1261. [CrossRef]

133. London, D.; Hunt, L.E.; Schwing, C.R.; Guttery, B.M. Feldspar thermometry in pegmatites: Truth and consequences. Contrib. Miner. Pet. 2019, 175, 8. [CrossRef]

134. Hutton, D.H.W. Granite emplacement mechanisms and tectonic controls: Inferences from deformation studies. Trans. R. Soc. Edinb. Earth Sci. 1988, 79, 245-255. [CrossRef]

135. Neves, S.P.; Vauchez, A.; Archanjo, C.J. Shear zone-controlled magma emplacement or magma-assisted nucleation of shear zones? Insights from northeast Brazil. Kimberl. Struct. Cratonic Lithosphere 1996, 262, 349-364. [CrossRef]

136. Tursi, F.; Spiess, R.; Festa, V.; Fregola, R.A. Hercynian subduction-related processes within the metamorphic continental crust in Calabria (southern Italy). J. Metamorph. Geol. 2020. [CrossRef]

137. Rosenberg, C.L. Deformation of partially molten granite: A review and comparison of experimental and natural case studies. Int. J. Earth Sci. 2001, 90, 60-76. [CrossRef]

138. Tullis, J.; Yund, R.A. Diffusion creep in feldspar aggregates: Experimental evidence. J. Struct. Geol. 1991, 13, 987-1000. [CrossRef]

139. Fitz Gerald, J.D.; Harrison, T.M. Argon diffusion domains in K-feldspar I: Microstructures in MH-10. Contrib. Miner. Pet. 1993, 113, 367-380. [CrossRef]

140. Altenberger, U.; Wilhelm, S. Ductile deformation of K-feldspar in dry eclogite facies shear zones in the Bergen Arcs, Norway. Tectonophysics 2000, 320, 107-121. [CrossRef]

141. Rosenberg, C.L.; Stünitz, H. Deformation and recrystallization of plagioclase along a temperature gradient: An example from the Bergell tonalite. J. Struct. Geol. 2003, 25, 389-408. [CrossRef]

142. Pennacchioni, G.; Menegon, L.; Leiss, B.; Nestola, F.; Bromiley, G. Development of crystallographic preferred orientation and microstructure during plastic deformation of natural coarse-grained quartz veins. J. Geophys. Res. Solid Earth 2010, 115. [CrossRef]

(C) 2020 by the authors. Licensee MDPI, Basel, Switzerland. This article is an open access article distributed under the terms and conditions of the Creative Commons Attribution (CC BY) license (http://creativecommons.org/licenses/by/4.0/). 